\title{
DEFYING GRAVITY: THE DEVELOPMENT OF STANDARDS IN THE INTERNATIONAL PROSECUTION OF INTERNATIONAL ATROCITY CRIMES
}

\author{
Matthew H. Charity \\ INTRODUCTION
}

The International Criminal Court ("ICC") is now entering its second decade of existence. ${ }^{1}$ As a young institution, the ICC is still in the process of setting norms as to its own scope and jurisdiction. Thus far, one of the key jurisdictional questions that has defied resolution is the place of complementarity in deciding whether certain criminal issues of international concern should be tried before the ICC or national tribunals. ${ }^{2}$ Although the Rome Statute crystallizes definitions of core international crimes that may be tried before the ICC, the process of determining whether to leave jurisdiction with the nation or allow jurisdiction to lie with the ICC continues to lack structure and appropriate guidance.

In the midst of this norm-creating and norm-setting moment in the codification of international criminal law, the ICC has, at times, set an overly high bar for the hearing of international criminal law cases. In doing so, the ICC may not only be forgoing the opportunity to prosecute alleged

* Associate Professor of Law, Western New England University School of Law. J.D. Columbia Law School, 1999. A.B. Princeton University, 1996. I wish to thank Kim Chanbonpin, Sudha Setty, Charles Jalloh, as well as the participants of the 2011 Northeast People of Color Legal Scholarship Conference, where I presented an earlier draft of this paper, for their thoughtful comments and suggestions. Thanks also to my research assistants, Melissa Lussier and Katherine Tonkovich, and our research librarian Renee Rastorfer, for their work. Unless otherwise noted, translations from the French (and concomitant errors) are my own.

1. See Rome Statute of the International Criminal Court, July 17, 1998, 2187 U.N.T.S. 90 (entered into force on July 1, 2002) [hereinafter Rome Statute], available at $\mathrm{http} / / /$ untreaty.un.org/cod/icc/statute/english/rome_statute $\% 28 \mathrm{e} \% 29$.pdf.

2. The drafters of the ICC made the requirement that the ICC complement states' domestic jurisdictions a central component of its authority. See Rome Statute, supra note 1, pmbl. If 10 ("Emphasizing that the International Criminal Court established under this Statute shall be complementary to national criminal jurisdictions.") \& art. 1 ("It shall be a permanent institution and ... shall be complementary to national criminal jurisdictions."). Pmbl I 6 of the Rome Statute also recalls "that it is the duty of every State to exercise its criminal jurisdiction over those responsible for international crimes." See also JANN K. KLEFFNER, COMPLEMENTARITY IN THE ROME STATUTE AND NATHONAL CRIMINAL JURISDICTIONS 4 (2008) (noting that the ICC "is supposed to function as a permanent reserve court, which steps in when effective national suppression of ICC crimes is absent" (internal quotes omitted)). 
war criminals, but is also setting an example for States Parties ${ }^{3}$ to avoid domestic prosecutions. This is not a new phenomenon; the question of what standard for prosecution should be set by the international community has arisen repeatedly over the past century and again in recent years, and it is a fly in the ointment of international criminal justice.

Different and conflicting approaches have already been voiced, ${ }^{4}$ lending urgency to the project of clarifying complementarity during this norm-setting phase in the work of the ICC. This Article recommends a new normative complementary framework for application of core crimes in national jurisdictions-a necessary step in order to strengthen the ICC's ability to act as an effective body in punishing war criminals, improving accountability of governments complicit in atrocity crimes, and deterring future atrocities.

Emblematic of this problem is the case of Bosco Ntaganda, a third-incommand of the Congolese rebel group Forces Patriotiques pour la Liberation du Congo (FPLC). ${ }^{5}$ The Office of the Prosecutor for the ICC ${ }^{6}$ had alleged that Ntaganda engaged in the war crime of conscription of child soldiers, in addition to crimes against humanity and other crimes. ${ }^{7}$ The Pre-

3. For a list of current States Parties, those sovereign States that have ratified or acceded to the Rome Statute, see The States Parties to the Rome Statute, InTERNATIONAL CRIMINAL CouRT, http://www.icc-cpi.int/en_menus/asp/states\%20parties/Pages/the\%20states\% 20parties\%20to\%20the\%20rome\%20statute.aspx (last visited May 12, 2013).

4. See generally William A. Schabas, Victor's Justice: Selecting "Situations" at the International Criminal Court, 43 J. MARSHALL L. Rev. 535, 538 (2010) (discussing limitations on ICC jurisdiction as a reserve court).

5. See infra Part I.C.

6. See Rome Statute, supra note 1, art. 42(1) (establishing the Office of the Prosecutor and its mandate to "act independently as a separate organ of the Court. It shall be responsible for receiving referrals and any substantiated information on crimes within the jurisdiction of the Court, for examining them and for conducting investigations and prosecutions before the Court").

7. Situation in the Democratic Republic of Congo, Decision on the Prosecutor's Application for Warrants of Arrest, Case No. ICC-01/04-01/07, ๆๆ 25, 34, 40 (Feb. 10, 2006), available at http://www.icc-cpi.int/iccdocs/doc/doc530350.pdf [hereinafter PTC I Warrants Decision] (noting that domestic courts were to some extent dealing with other allegations with regard to Ntaganda). It should be noted that Ntaganda was twice offered a role within the Congolese Army - first in January 2005 (see D.R. Congo: Army Should Not Appoint War Criminals, Human RighTs WaTCH (Jan. 14, 2005), http://www.hrw.org/ news/2005/01/13/dr-congo-army-should-not-appoint-war-criminals), and then again in 2009 (see Human Rights Watch, "You Will Be Punished": AtTacks on Civilians IN EASTERN CONGO 129 (2009), available at http://www.hrw.org/sites/default/files/reports/ drc1209webwcover2.pdf). Ntaganda again left the army in April 2012 (see D.R. Congo: Bosco Ntaganda Recruits Children by Force, HuMAN Rights WaTCH (May 16, 2012), http://www.hrw.org/news/2012/05/15/dr-congo-bosco-ntaganda-recruits-children-force), and has for some months been absent from public scrutiny (see David Smith, Hunting the Terminator: Congo Continues Search for Bosco Ntaganda, THE GuARDIAN (Nov. 28, 2012), http://www.guardian.co.uk/world/2012/nov/28/terminator-search-bosco-ntaganda-congo). 
Trial Chamber of the ICC recognized that the Democratic Republic of Congo was unwilling or unable to prosecute Ntaganda for the alleged war crimes, ${ }^{8}$ leaving criminal accountability for those crimes to the mechanisms of international criminal justice. However, the ICC Pre-Trial Chamber-a chamber within the ICC with the responsibility for threshold jurisdictional questions-acting without sufficient guidance, opined that the ICC was simply not the appropriate venue to try individuals such as Ntaganda. ${ }^{9} \mathrm{Had}$ the Pre-Trial Chamber's opinion stood, it would have legitimized the impunity of Ntaganda and cemented the precedent of a narrow jurisdiction at the ICC, and that would enable the impunity of others like Ntaganda. ${ }^{10}$ Had that occurred, it would have indicated a lost opportunity for the ICC, nations interested in prosecuting war crimes, and the international community as a whole. This Article seeks, in part, to enable discourse on how to broaden ICC's jurisdiction through means at both the domestic and international levels. ${ }^{11}$

Part I analyzes the problem of the current trajectory of the ICC with regard to its jurisdictional scope. Looking at the development of transnational and international responses to atrocity crimes, including its burst of development in the last twenty-five years, this article recognizes that the Rome Statute was drafted with the intention of covering a broader range of cases than the ICC is currently handling. The intended scope includes the prosecution of alleged war criminals who were at senior, midlevel, and lower levels of authority in committing grave crimes. However, the potential scope of the ICC to reach such actors has been progressively narrowed since the inception of the Rome Statute due to prosecutorial discretion and resource constraints at the international level. This problem is exemplified by the 2006 Pre-Trial Chamber decision not to issue a warrant of arrest for Bosco Ntaganda, a high-ranking alleged war criminal in the Democratic Republic of Congo; this is rectified, in part, by the ICC Appeal Chamber's review of that decision. Part I also addresses how national courts have failed to live up to their international obligations in not defining gravity ${ }^{12}$ broadly so as to encourage the ICC to find that the

8. PTC I Warrants Decision, supra note 7, 140.

9. Id. | 89.

10. See infra notes 65-70 for the Appeals' response.

11. The matter of Bosco Ntaganda's case at the ICC is discussed in more detail infra in Part I.C.

12. While the terms "grave" and "gravity" were used often throughout the twentieth century in the context of describing the harms that the international community sought to prevent, the terms did not require precision until their use created a jurisdictional trigger for the International Criminal Tribunals. See Margaret M. deGuzman, How Serious Are International Crimes? The Gravity Problem in International Criminal Law, 51 ColuM. J. TRANSNAT'L L. 18, 21-22 (2012) (arguing that although there is common understanding that a gravity standard has been met in cases of mass atrocities such as those in Rwanda and the former Yugoslavia, the definition of gravity has not yet been properly established). 
prosecution of Ntaganda and others who are similarly situated are within its jurisdiction.

Part II considers the historical context of international criminal justice in two respects. First, it reviews efforts at establishing extra-national criminal justice mechanisms and notes that, historically, effective development of transnational legal processes has depended on nations engaging in norm-setting dialogue that has strengthened and underpinned international criminal justice mechanisms by giving meaning to the definitions used by international tribunals and the scope of those tribunals' work. Second, it argues that the jurisdictional narrowing currently occurring at the ICC is not a new phenomenon, but instead, it reflects a historical pattern of the international community attempting to define the jurisdiction of international criminal processes broadly, only to see those processes narrowed and limited over time. As such, the current narrowing of jurisdiction puts the ICC at the brink of lost opportunity to make permanent an institution that can be truly effective in prosecuting and deterring atrocity crimes.

Part III analyzes the slow process and the confusion in the development of the law divided by the roles of the Office of the Prosecutor, the Pre-Trial Chamber, and the Appeals Chamber. The Article suggests further development at the domestic level in order to set broader jurisdictional norms for the ICC, which the ICC would then be permitted under the Rome Statute to consider. ${ }^{13}$

This Article concludes by suggesting a new normative framework to ensure that the ICC can defy historical patterns and live up to its potential. In particular, this Article recommends that States Parties to the Rome Statute engage further in transnational legal processes with regard to the question of complementarity. By engaging in interaction, debate, and discourse, States Parties can enable a broader understanding of what constitutes gravity within national courts, thereby engaging in positive norm-setting that resonates with the ICC as it continues to build the architecture for its own determinations of jurisdiction. Such a process would support efforts to allow for an interpretation of those crimes that would give guidance to victim groups, world leaders, and the world community such that binding internalization of norms would work toward the ultimate goal of protecting vulnerable populations.

13. See Rome Statute, supra note 1, art. 21(1)(c) (requiring that the I.C.C. consider "general principles of law derived by the Court from national laws of legal systems of the world including, as appropriate, the national laws of States that would normally exercise jurisdiction over the crime, provided that those principles are not inconsistent with this Statute and with international law and internationally recognized norms and standards," but only where the Statute, treaties, and principles and rules of international law are not clearly applicable). 


\section{THE NARROWING SCOPE OF ICC'S JURISDICTION}

The ICC is still in the early phases of its development. As such, its norms with regard to questions of jurisdiction are still malleable and open to interpretation. Yet the current trends suggest that the ICC's jurisdiction has narrowed significantly from what was envisioned by the Rome Statute. National courts are not picking up the slack and prosecuting atrocity crimes. As a result of these two trends, the ICC is now at risk of falling far short of what the framers of and signatories to the Rome Statute intended.

\section{A. The Rome Statute and Complementarity}

In recent years, a number of cases relating to international criminal law have focused on genocide, crimes against humanity, and war crimes (together referred to as "atrocity crimes"). ${ }^{14}$ The cases vary depending on the situation: some cases and situations are before the ICC, a permanent institution with broad prospective jurisdiction over atrocity crimes. ${ }^{15}$ At the same time, a number of ad hoc international institutions have been created to deal with specific post-conflict situations such as the International Criminal Tribunals for Yugoslavia and Rwanda, ${ }^{16}$ the Extraordinary Chambers of the Court of Cambodia, ${ }^{17}$ and the Special Court for Sierra Leone. ${ }^{18}$ Additionally, national trials in Guatemala, ${ }^{19} \mathrm{Peru}^{20}$ and other

14. See, e.g., David Scheffer, Closing the Impunity Gap in U.S. Law, 8 Nw. U. J. INT'L Hum. RTs. 30, 2 (2009).

15. See Rome Statute, supra note 1, pmbl. (recognizing that the State Parties to the Rome Statute are "[d]etermined to put an end to impunity for the perpetrators of [the most serious crimes of concern to the international community as a whole] and thus to contribute to the prevention of such crimes...").

16. The International Criminal Tribunal for Yugoslavia (ICTY) was established in 1993 to create a mechanism for accountability over the war crimes and atrocities that occurred in the early 1990s in the various conflicts occurring in the former Yugoslavia. See S.C. Res. 827, U.N. Doc. S/RES/827 (May 25, 1993). Likewise, the International Criminal Tribunal for Rwanda (ICTR) was established in 1994 to seek accountability for the Rwandan Genocide and other grave breaches of international law. See S.C. Res. 955, U.N. Doc. S/RES/955 (Nov. 8, 1994). Both the ICTY and ICTR are considered groundbreaking as the first post-Nuremberg international criminal tribunals, and the first to be set up through a Security Council resolution under Chapter VII of the Charter of the United Nations. See Erik Mose, Main Achievements of the ICTR, 3 J. INT'L CRIM. JUST. 920,927 (2005).

17. See G.A. Res. 57/228, U.N. Doc. A/RES/57/228 (May 27, 2003) (The Extraordinary Chambers of the Court of Cambodia is most accurately characterized as a hybrid tribunal since it is a national court that was created in a coordinated effort with the United Nations. It is staffed by national and international judges and applies international laws. Its mandate includes trying former Khmer Rouge members for war crimes and atrocities committed in Cambodia during the 1970s.).

18. See S.C. Res 1315, U.N. Doc. S/RES/1315 (Aug. 14, 2000) (The Special Court for Sierra Leone was established by the United Nations and Sierra Leone as a hybrid entity - a national court that was created in a coordinated effort with the United Nations, is staffed by 
places engage in domestic interpretations of international law and the nature of atrocity crimes. ${ }^{21}$

The most basic common thread among all of these aforementioned courts is their goal of seeking accountability for the worst crimes offending ethnic and national societies as well as the international community. The work of these courts should be considered as national and international in nature, ${ }^{22}$ since they address crimes and actions that both the international and national communities would like to punish and deter in the future. In order to be effective at this work and to maintain legitimacy at both levels, courts must rely on both national and international mechanisms of prevention. ${ }^{23}$ The aspiration of this multi-level system is that those who committed atrocity crimes - whether as senior leaders of a group, mid-level authorities or lower level operatives - can be prosecuted and held accountable for their actions. ${ }^{24}$

The difficulty arises in that international and national mechanisms have different strengths, limits, and, to a certain extent, deontological purposes. The Rome Statute ${ }^{25}$ creates the ICC as a body independent from

national and international judges, and applies international laws. Its purpose is to try those accused of atrocity crimes and war crimes committed during the internal conflicts in Sierra Leone that began in 1996.).

19. See World Report 2012: Guatemala, HuMAN RigHTS WATCH, http://www.hrw.org/ world-report-2012/guatemala (last visited May 12, 2013) (Since 2009, sporadic trials for war crimes occurring during Guatemala's decades-long civil war have been ongoing. They represent a small measure of accountability for the number of atrocity crimes that occurred during the conflict.).

20. See Simon Romero, Peru's Ex-President Convicted of Rights Abuses, N.Y. Times, Apr. 7, 2009, available at http:/www.nytimes.com/2009/04/08/world/americas/ 08fujimori.html?_r=0 (In 2009, Peruvian courts applied national and international law to convict former Peruvian president Alberto Fujimori of, among other charges, crimes against humanity in the killings of twenty-five people by military death squad in the 1990s.).

21. The obligation of national courts to function on two levels - both domestic and international - is discussed in Part I.C. See infra pp.14-18.

22. See, e.g., Rome Statute, supra note 1, pmbl. (recognizing that the States Parties to the Rome Statute are "[d]etermined to put an end to impunity for the perpetrators of [the most serious crimes of concern to the international community as a whole] and thus to contribute to the prevention of such crimes.").

23. See, e.g., Rome Statute, supra note 1, pmbl ("Affirming that the most serious crimes of concern to the international community as a whole must not go unpunished and that their effective prosecution must be ensured by taking measures at the national level and by enhancing international cooperation ... .); see also Markus Benzing, The Complementarity Regime of the International Criminal Court: International Criminal Justice Between State Sovereignty and the Fight Against Impunity, in 7 MAX PLANCK Y.B. OF UNITED NATIONS L. 591,597 (2003) (suggesting the ICC could be used to protect against victor's justice by the state).

24. See generally C. H. Beck et al., Commentary on the Rome Statute of the International Criminal Court: Observers' Notes, Article by Article (Otto Triffterer $2 \mathrm{~d}$ ed. 2008) [hereinafter Commentary].

25. By a vote of 120 to 7 (with twenty-one states abstaining), the international community put forth the Rome Statute, allowing for a complementary supranational court to 
and not directly controlled by the States Parties to the treaty of the court or the United Nations, but in relationship with the United Nations system. ${ }^{26}$ While a state, in dealing with harms occurring within that state's jurisdiction, may take measures at a national level through legislation, administrative mandate, or judicial action, in any case, it would continue to act as the state. As such, the state may be placing the interest of the state ahead of "justice," which is sometimes amorphous and uneasily defined. ${ }^{27}$ In those circumstances, the potential exists for interference in the judicial processes of the state by parts of the state apparatus seeking to prevent prosecution of crimes for political reasons or otherwise. ${ }^{28}$

The Rome Statute attempts to account for that concern with its provisions on complementarity and admissibility by striking a balance and allowing the States Parties to take the lead on prosecuting atrocity crimes by making the following inadmissible to the ICC: (1) the state that has jurisdiction over the case is investigating or prosecuting the crime; (2) the investigating or prosecuting state is unwilling or unable to genuinely carry out the investigation or prosecution; or (3) after an investigation, the state with jurisdiction has decided not to prosecute, but the decision resulted from the unwillingness or inability of the state to genuinely prosecute; and (4) the case does not have sufficient gravity to justify further action by the Court. ${ }^{29}$ Under this standard, States Parties to the Rome Statute would have the first opportunity to engage in a good faith investigation into the alleged crimes. $^{30}$

The complementary nature of the ICC has raised many questions about the demarcation of responsibility between the national courts and the

try alleged perpetrators of some of the crimes of primary interest to the international community. M. Cherif Bassiouni, The Statute of the InTERnational Criminal Court: A DOCUMENTARY HISTORY 32 (1998) [hereinafter DOCUMENTARY HISTORY] (For more information on the Rome Statute, see generally COMMENTARY, supra note 24).

26. See generally COMMENTARY, supra note 24.

27. KLEFFNER, supra note 2, at 322 (highlighting the distorting effects of domestic political pressures).

28. Such interference occurred in conjunction with the lack of domestic prosecution of high-ranking officials with regard to the situation in Darfur, Sudan, alleging genocide, war crimes, and crimes against humanity. See generally Matthew H. Charity, The Criminalized State: The International Criminal Court, the Responsibility to Protect, and Darfur, the Republic of Sudan, 37 Oноо N.U. L. REV. 67 (2011). The refusal to arrest Omar al-Bashir by government officials in Kenya stands as an example of that interference challenged by internal judicial processes, as the Kenyan Supreme Court in November 2011 found that alBashir's arrest must go into effect should he visit Kenya in the future. See James Macharia, Kenyan Court Issues Arrest Order for Sudan's Bashir, ReuTERs (Nov. 28, 2011, 1:50 PM EST), http://www.reuters.com/article/2011/11/28/us-kenya-bashir-icc-idUSTRE7AR0YA20 111128. Likewise, such interference has occurred with regard to the ongoing situation in the Democratic Republic of Congo. See infra Part I.C. (discussing the case of Bosco Ntaganda).

29. See Rome Statute, supra note 1, art. 17.

30. See Rome Statute, supra note 1, pmbl. (stating that the ICC "shall be complementary to national criminal jurisdictions ..."). Id. art. 1. 
ICC. Much of the scholarship relating to the complementary nature of the ICC's jurisdiction relates to antagonistic complementarity ${ }^{31}$ - the ability of the ICC to intervene by taking jurisdiction where the state with primary jurisdiction fails to genuinely investigate or prosecute credible allegations of crimes falling within the ICC's jurisdiction. ${ }^{32}$ Other scholars focus on the obligation of national courts to prosecute atrocity crimes, noting the possible obligation to implement the laws against international crimes "subject to the ICC's jurisdiction in their national laws and furthermore to establish extra-territorial, universal jurisdiction which enables their national criminal courts to adjudicate these crimes even if they have been committed abroad by a foreign national. ${ }^{33}$

Even states that do not recognize an obligation on the part of States Parties to incorporate those criminal provisions into their internal law have frequently adopted the language of the Rome Statute to increase the state's ability to cooperate with the ICC, both in support of the Rome Statute and, potentially, to enforce decisions taken by the Security Council. ${ }^{34}$

If the ICC fails to use this norm-setting moment in the codification of

31. By antagonistic complementarity, I reference the theory that the ICC will serve to shame and blame states that fail to properly prove willingness and ability to prosecute crimes. See, e.g., KLEFFNer, supra note 2, at 320 (citing A. CASSESE, INTERNATIONAL CRIMINAL LAW 353 (OUP, Oxford 2003), stating as one of complementarity's chief merits "the indirect but powerful incentive to [national courts] becoming more operational and effective, inherent in the power of the ICC to substitute for national judges, whenever they are not in a position to dispense justice or they deliberately fail to do so [ . . . ."); see also Elena Baylis, Reassessing the Role of International Criminal Law: Rebuilding National Courts Through Transnational Networks, 50 B.C. L. REV. 1, 51 (2009) ("The primary role that the ICC was expected to play in post-conflict states parties was to spur domestic prosecution of known perpetrators to avoid the perceived loss of face and sovereignty costs of having the ICC pursue those prosecutions internationally."). This is distinct from the concept of (1) negative complementarity, which does not of necessity seek compliance through a shaming mechanism, but only empowers the ICC to act where there is a lack of action by national courts, and (2) positive complementarity, which looks to the ICC to engage with states that otherwise would have jurisdiction to further enable those states to prosecute alleged crimes.

32. See e.g., Jann K. Kleffner, The Impact of Complementarity on National Implementation of Substantive International Criminal Law, 1 J. INT'L CRIM. J. 86, 87 (2003) [hereinafter Kleffner, The Impact of Complementarity].

33. Id. at $\mathbf{n} .18$ (quoting the Memorie van Toelichting Wet Internationale Misdrijven, Dutch Explanatory Memorandum on Substantive Implementing Legislation Kamerstukken II 2001/02, 28 337, nr. 3 (MvT) pp. 2 \& 18).

34. See, e.g., id. at n. 13 (citing Spanish Progress Report on ratification and implementation of the Rome Statute to the Council of Europe, available at http://www.coe.int/t/dlapil/cahdi/Source/ICC/4th\%20Consult $\% 20 I C C \% 20 \% 282006 \% 29 \% 2$ $008 \% 20 \mathrm{E} \% 20$ Spain.pdf); see also Scheffer, supra note 14, at 3 ("Paradoxically, even as a non-party to the Rome Statute of the ICC (the 'Rome Statute'), the United States today essentially stands more exposed to its jurisdiction than do American allies that have modernized their criminal codes."). 
international criminal $\mathrm{law}^{35}$ to expand on protections to those subject to atrocity crimes, States Parties seeking to avoid the time, expense, and political repercussions of their own prosecutions would have a strong argument that domestic prosecutions would engage in overreach. The expansion of international criminal law represented by the creation of the ICC would, in effect, make way at this early stage for the contraction of international criminal justice.

\section{B. The Gravity Standard Since the Inception of the International Criminal} Court

In negotiating the Rome Treaty during the 1990s, drafters drew much of the language defining the particular underlying crimes over which the ICC would have jurisdiction from recent precedent: the Convention on the Prevention and Punishment of the Crime of Genocide; ${ }^{36}$ the Statutes for the International Criminal Tribunals for the Former Yugoslavia ${ }^{37}$ and Rwanda; ${ }^{38}$ and the Draft Code of Crimes against the Peace and Security of Mankind. $^{39}$

The interaction and transnational dialogue that was prevalent after the U.S. Civil War, the Franco-Prussian War, and the World Wars ${ }^{40}$ at all times demanded an interpretation of protection from atrocities, and the extent of punishment for wrongdoing was lacking in the context of the development of the ICC. For the majority of the pre-Rome Statute period, there existed little interest in the creation of a fairly powerful permanent institution with components of criminal law authority. Because the emphasis of pre-Rome Statute criminal justice efforts was largely retrospective and specific

35. See generally, Lisa J. LaPlante, The Domestication of International Criminal Law: A Proposal for Expanding the International Criminal Court's Sphere of Influence, $43 \mathrm{~J}$. MARSHALL L. REV. 635, 639-42 (2010); see generally Schabas, supra note 4.

36. See generally Convention on the Prevention and Punishment of the Crime of Genocide, art. 2, Dec. 9, 1948, 78 U.N.T.S. 277, available at http://wwwl.umn.edu/ humanrts/instree/xlcppcg.htm (defining genocide in legal terms for use in the international community).

37. See generally U.N. Secretary-General, Report of the Secretary General Pursuant to Paragraph 2 of the Security Council Resolution 808, \12, U.N. Doc. S/25704 (May 3, 1993) (statute establishing jurisdiction and parameters for the ICTY); S.C. Res. 808, U.N. Doc. S/RES/808 (Feb. 22, 1993) (deciding that an international tribunal was necessary to try atrocity crimes in the former Yugoslavia).

38. See generally S.C. Res. 955, U.N. Doc. S/RES/955 (Nov. 8, 1994) (establishing the ICTR and annexing its statute).

39. See generally Draft Code of Crimes against the Peace and Security of Mankind, Int'l Law Comm'n, U.N. Doc. A/CN.4/L.532; GAOR, 48th Sess., Supp. No. 10 (1996) (reporting to the U.N. General Assembly with a code that derives from the Articles of the Nuremberg Charter, which also derive description of criminal acts from the World War I Commission).

40. The transnational legal process engaged in after each of these conflicts is discussed in detail in Part II infra. 
(responding to previous problems of which we have become aware from recent experience) as opposed to developing best responses for the problems that we have today or are likely to face prospectively, much of the discussion has focused on the application of general principles of criminal law regarding rights of the accused, the application of lex lata ${ }^{41}$ at a time of legal development, and interpretation of treaty provisions in a strict sense such that the defendant benefits from any confusion in the law of the ICC. ${ }^{42}$

While this incrementalism and limited scope may give comfort to States Parties signing the Rome Statute that smaller steps will prevent surprise and allow for the Office of the Prosecutor to develop clear and cogent theories of a fairly narrow reading of the case, this very behavior undermines some of the purpose of the ICC. ${ }^{43}$ Further, based on the observed difficulty of prosecution by an international tribunal, criminal trials undertaken by individual states may suffer from every structural and procedural weakness of the ICC, but without the perceived autonomy or international legitimacy (in many cases) that the ICC has. ${ }^{44}$

\section{The Case of Bosco Ntaganda and the ICC's Problematically Narrow Jurisdiction}

The difficulties are best seen in considering norm development within the ICC's structure. Article 58 of the Rome Statute requires that the PreTrial Chamber ${ }^{45}$ issue a warrant of arrest if after examining the application and the evidence submitted by the Prosecutor it determines that "[t]here are reasonable grounds to believe that the person has committed a crime within

41. Indeed, questions of whether the ICC would focus only on settled law (lex lata) and not deal with more poorly defined law in development (lex ferenda) influenced the selection of these cognizable international crimes and forestalled the implementation of a defined crime of aggression.

42. See Rome Statute, supra note 1, art. 24 (Non-retroactivity ratione personae).

43. See, e.g., Uwe Ewald, 'Predictably Irrational' - International Sentencing and Its Discourse against the Backdrop of Preliminary Empirical Findings on ICTY Sentencing Practices, 10 INT'L CRIM. L. REV. 365, 383 (2010) (noting that "acceptance of penalties is directly related to an understanding of usefulness of criminal punishment"); Julian Ku \& Jide Nzelibe, Do International Criminal Tribunals Deter or Exacerbate Humanitarian Atrocities?, 84 WASH. U. L. REV. 777, 780-81 (2006) (challenging the notion that International Criminal Tribunals actually serve to deter crimes).

44. The resistance received by certain states that were more likely to allow for trials of higher ranking officials under a theory of universal jurisdiction evidences this problem: the financial incentives to allow for greater trade and to continue involvement in regional organizations may influence states such as Afghanistan, Belgium, and Spain to create laws that will limit rather than further enhance jurisdiction.

45. See generally Rome Statute, supra note 1, art. 34(b) (establishing a Pre-Trial Chamber of the ICC to deal with, among other duties, admissibility of cases to the Trial Chamber of the ICC). 
the jurisdiction of the Court. ${ }^{, 46}$ Due to complementarity concerns and the ICC's reserve status, the ICC only has jurisdiction where the case is of sufficient gravity for the higher level of international consideration. ${ }^{47}$

On February 10, 2006, Pre-Trial Chamber I of the ICC refused to grant a warrant for the arrest of Bosco Ntaganda, the third-in-command of the Forces Patriotiques pour la Liberation du Congo (FPLC), the military arm of the Union des Patriotes Congolais (UPC).$^{48}$ The Pre-Trial Chamber recognized that Ntaganda conscripted, trained, and forced children under the age of fifteen to participate in hostilities. ${ }^{49}$ Ntaganda was subject to an arrest warrant in Bunia, Democratic Republic of Congo, on charges of joint criminal enterprise, arbitrary arrest, torture, and complicity of assassination..$^{50}$ Although the arrest warrant was issued, the Democratic Republic of Congo did not seek Ntaganda for the conscription of child soldiers, which would be considered an atrocity crime. ${ }^{51}$

In reviewing the case against Ntaganda, the Pre-Trial Chamber decided to look at whether a claim would be admissible to the $\mathrm{ICC}^{52}$ prior to making a determination of whether to issue a warrant for Ntaganda's

46. Rome Statute, supra note 1, art. 58(1)(a).

47. While not probative of the proper interpretation, the travaux préparatoires may be considered to confirm an understanding of a treaty, under a customary law application of the Vienna Convention of the Law of Treaties, art. 32(a), May 23, 1969, 1155 U.N.T.S. 351. One can, therefore, look to The Report of the Preparatory Committee on the Establishment of an International Criminal Court, Vol. I, G.A. 51st Sess., Supp. No. 22, A/51/22 (1996) to confirm Article 17's limit on the scope of jurisdiction: "There was general agreement concerning the importance of limiting the jurisdiction of the Court to the most serious crimes of concern to the international community as a whole, as indicated in the ... preamble, to avoid trivializing the role and functions of the Court and interfering with the jurisdiction of national courts." DOCUMENTARY HISTORY, supra note 25, at 394.

48. The Forces Patriotiques pour la Libération du Congo (FPLC) was the military wing of the Union des Patriotes Congolais, a Congolese political and militia group formed in the early 2000s. See Justice in the Democratic Republic of Congo: A Background, HaGue JUSTICE PORTAL (Dec. 17, 2009), http://www.haguejusticeportal.net/index.php?id=11284. The FPLC was suspected of engaging in numerous war crimes, including the conscription of child soldiers and the killing of civilians and U.N. peacekeepers. Situation in the Democratic Republic of Congo, HAGUE JUSTICE PORTAL, http://www.haguejusticeportal.net/index. php?id=6174 (last visited May 12, 2013).

49. See Justice in the Democratic Republic of Congo: A Background, Hague Justice PORTAL (Dec. 17, 2009) http://www.haguejusticeportal.net/index.php?id=11284; see also DR Congo: Arrest Bosco Ntaganda for ICC Trial, Human Rights WATCH (Apr. 13, 2012), http://www.hrw.org/news/2012/04/13/dr-congo-arrest-bosco-ntaganda-icc-trial (detailing allegations of the various war crimes in which Ntaganda was involved, including ethnic cleansing, rape, torture and the conscription and training of child soldiers).

50. PTC I Warrants Decision, supra note 7, ๆๆ 25, 34, 40 (acknowledging that domestic courts were adequately dealing with these allegations with regard to Ntaganda).

51. PTC I Warrants Decision, supra note 7, ๆा 25, 34, 40 (discussing the failure of domestic courts to address the conscription issue).

52. See Rome Statute, supra note 1, arts. 17, 19, 53, 58. 
arrest. $^{53}$ The Pre-Trial Chamber then set a standard that matched the Prosecution's own prioritization of cases using a gravity standard, ${ }^{54}$ "that, as a general rule, the Office of the Prosecutor should focus its investigative and prosecutorial efforts and resources on those who bear the greatest responsibility, such as the leaders of the State or organisation allegedly responsible for those crimes." $\$ 55$

Therefore, the Pre-Trial Chamber set up a definition of a gravity threshold for admissibility based on the language of the Rome Statute that asked three questions, all of which had to be answered affirmatively for the case to be considered admissible. ${ }^{56}$ First, the Pre-Trial Chamber asked whether the conduct alleged was "systematic" or occurred on a "large scale. ${ }^{.57}$ The next question was whether the potential defendant can be considered a "senior leader" in committing the alleged war crimes. ${ }^{58}$ The final element was consideration of whether the role played by the potential defendant warranted admissibility to the ICC. ${ }^{59}$

The Pre-Trial Chamber recognized that the alleged policy/practice of

53. PTC I Warrants Decision, supra note 7, ๆf 17- 20.

54. Rome Statute, supra note 1, art. 17(1)(d), ("[T] he Court shall determine that a case is inadmissible where ... [t] the case is not of sufficient gravity to justify further action by the Court."

55. PTC I Warrants Decision, supra note 7, I 62 (quoting Paper on Some Policy Issues Before the Office of the Prosecutor, 7 (2003), http://www.amicc.org/docs/OcampoPolicyPaper9_ 03.pdf.)

56. PTC I Warrants Decision, supra note 7, 9 64. The Pre-Trial Chamber defined the gravity standard as follows:

any case arising from an investigation before the Court will meet the gravity threshold provided for in article 17(1)(d) of the Statute if the following three questions can be answered affirmatively:

i) Is the conduct which is the object of a case systematic or large scale (due consideration should also be given to the social alarm caused to the international community by the relevant type of conduct)?; ii) Considering the position of the relevant person in the State entity, organisation or armed group to which he belongs, can it be considered that such person falls within the category of most senior leaders of the situation under investigation?; and iii) Does the relevant person fall within the category of most senior leaders suspected of being most responsible, considering (1) the role played by the relevant person through acts or omissions when the State entities, organisations or armed groups to which he belongs commit systematic or large-scale crime within the jurisdiction of the Court; and (2) the role played by such State entities, organisations or armed groups in the overall commission of crimes within the jurisdiction of the Court in the relevant situation?

Id.

57. Id.

58. Id.

59. Id. See also Paper on Some Policy Issues Before the Office of the Prosecutor, 6 (2003), http://www.amicc.org/docs/OcampoPolicyPaper9_03.pdf. 
enlisting and conscripting children under the age of fifteen into the FPLC, and causing them to participate in active hostilities, caused social alarm; the Pre-Trial Chamber looked at the scale of the conduct and found it to be regional instead of national and, therefore, not widespread. ${ }^{60}$ The Pre-Trial Chamber then concluded that Ntaganda's role in the organization as third in command of the military wing meant that he had little control over the political wing of the organization and that his responsibilities were more limited than the most senior leaders of the organization. ${ }^{61}$ Finally, the PreTrial Chamber considered Ntaganda's inability to sign agreements binding the political organization ${ }^{62}$ and the lack of social alarm at his acts ${ }^{63}$ showed that his arrest would not serve as a deterrent to other leaders. Because of these findings, the Pre-Trial Chamber denied the requested warrant of arrest and concluded that the prosecutor should focus its efforts on others who were the most senior leaders. ${ }^{64}$

The Appeals Chamber ${ }^{65}$ pointed out numerous flaws in the Pre-Trial Chamber's analysis. First, it noted that Ntaganda was deeply involved with the recruiting of child soldiers, that the war crime with which he was charged did not require it be widespread, and that there was nothing in the Rome Statute that would allow for the subjective "social alarm test" that the Pre-Trial Chamber applied. ${ }^{66}$ Second, the Appeals Chamber concluded that failing to arrest Ntaganda would put a large number of alleged criminals on notice that they need not fear arrest, even for serious crimes. ${ }^{67}$ Under the Rome Statute, this deterrent effect is one of the purposes of maintaining a broad scope for admissibility of cases similar to that of Ntaganda. ${ }^{68}$ Third, even if Ntaganda was not the most senior leader in this conflict, lower and mid-level operatives sometimes are (and should be) arrested to help build a case against the most senior leaders. ${ }^{69}$ The Pre-Trial Chamber failed to

60. PTC I Warrants Decision, supra note 7, ๆ 72,84 (UPC/FPLC was merely a regional group operating only in the Ituri region.).

61. Id. ๆๆ $79,82,85,89$.

62. Id. $\uparrow \uparrow 86,87$.

63. The question of social alarm was not fully explained by the Pre-Trial Chamber, an issue raised in the review of the decision by the Appeals Chamber.

64. PTC I Warrants Decision, supra note 7, ๆा 86, 87.

65. See generally Rome Statute, supra note 1, art. 34(b) (establishing an Appeals Chamber for the ICC with jurisdiction to review decisions of the Pre-Trial Chamber and the Trial Chamber).

66. Situation in the Democratic Republic of the Congo, Judgment on the Prosecutor's Appeal against the Decision of Pre-Trial Chamber I entitled "Decision on the Prosecutor's Application for Warrants of Arrest, Article 58," Case No. ICC-01/04-169, 情 69-72 (July 13, 2006), available at http://www.icc-cpi.int/iccdocs/doc/doc183559.pdf [hereinafter Appeal of Pre-trial Chamber I].

67. Appeal of Pre-trial Chamber I, supra note 66, ๆf 73-77.

68. Id. ๆी 77-78.

69. Id. 977. 
acknowledge or apply these purposes of the Rome Statute. ${ }^{70}$

The potential effect of the initial failure to prosecute in the Ntaganda case may be profound. First, there was a ripple effect on other situations being considered for admissibility to the ICC. The decision not to prosecute Ntaganda led to the expansion of a loophole created by an agreement with the government of Uganda in 2003 in another case. ${ }^{71}$ Second, from a normsetting perspective, the Pre-Trial Chamber's decision not to prosecute gave rise to the practice of the ICC not prosecuting perpetrators other than those few most responsible. Indeed, in issuing a decision for the warrant of arrest of Omar al-Bashir, ${ }^{72}$ ICC Pre-Trial Chamber I noted in 2009 that the flawed test offered in the Ntaganda case was still the only standard for consideration by the ICC, presuming the ICC considered it appropriate to determine the admissibility of a case on gravity grounds. ${ }^{73}$

\section{Domestic Courts and International Legal Obligations}

The failure of the ICC to act in cases like that of Ntaganda is exacerbated by the lack of top-down pressure on domestic courts to prosecute, the failure of domestic courts to fulfill their international obligations, and the failure of State Parties to engage in transnational interaction and discussion regarding harms in violation of international principles and the adoption by states of mechanisms for the vindication of human rights. Adding to these shortcomings, the purported sanctioning tools of negative complementarity failed to provide a remedy to at risk populations.

\section{Lack of Top-Down Pressure}

Unfortunately, the same standards that lead to compliance pull may evidence the limits on complementarity's applicability. An ability to comply with the letter of the law - here, the terms of the Rome Statute may undermine some purposes of international criminal law. Prosecutorial

70. See Appeal of Pre-trial Chamber I, supra note 66.

71. See Emmanuel Mulondo \& Gerald Walulya, Uganda: 'No Amnesty for Rebel Leaders,' ALLAFRICA (Apr. 19 2006), http://www.allafrica.com/stories/200604180779.html; KLEFFNER, supra note 2, at 325 ("[T] he prosecutorial policy of limiting the action of the Office of the Prosecutor to a certain category of individuals found reflection in the amendment of the Amnesty Act, thus equally limiting the scope of potential national investigations and prosecutions to these persons.").

72. See Charity, supra note 28 , at $72-77$ (explaining the background of the situation in the Darfur region of Sudan, as well as allegations made against Omar al-Bashir).

73. Situation in Darfur, Sudan, In the Case of the Prosecutor v. Omar Hassan Ahmad alBashir (Omar al-Bashir), Case Decision on the Prosecution's Application for a Warrant of Arrest against Omar Hassan Ahmad Al Bashir, No. ICC-02/05-01/09, n. 51 (Mar. 04, 2009), available at http://www.icc-cpi.int/iccdocs/doc/doc639078.pdf. 
discretion allows States Parties wide latitude to refuse to try cases, and states are not under significant pressure to reach beyond the highest level offenders in their prosecutorial decisions.

In determining whether States Parties have complied with their international obligations to prosecute, the ICC first looks to the terms of the Rome Statute, ${ }^{74}$ the Elements of Crimes,${ }^{75}$ and the Rules of Procedure and Evidence. ${ }^{76}$ Second, the ICC looks to applicable treaties other than the Rome Statute, and principles and rules of international law including established principles of the Law of Armed Conflict. ${ }^{77}$ Lastly, only absent general principles of international law, the ICC considers principles derived from national laws of legal systems of the world, where those laws are not inconsistent with the Rome Statute, or with international law and internationally recognized norms and standards. ${ }^{78}$ Notwithstanding and separate from these recognized sources of law, the ICC may apply interpretations of principles and rules of law from its own previous decisions, which one might presume would not conflict with the Rome Statute or other international standards of international criminal law. ${ }^{79}$ None of these mechanisms put a significant amount of pressure on domestic courts to fulfill their international obligations.

\section{Transnational Legal Processes}

Were national courts more actively describing their own understanding of the core crimes, similar to the analyses that must be made in considering potential prosecutions by the ICC, there would be greater interaction among parties trying to achieve the goal of ending impunity, and helping to determine a causal law that might prevent harm to populations

74. Rome Statute, supra note 1, art. 21(1)(a) (lex specialis relating to statutory interpretation of ICC-instituted International Criminal Law).

75. See generally International Criminal Court, Elements of Crimes (2011), available at $\mathrm{http} / / / \mathrm{www}$. unhcr.org/refworld/docid/4ff5dd $7 \mathrm{~d} 2 . \mathrm{html}$.

76. See generally International Criminal COURT, Rules of Procedure AND EVIDENCE (Sept. 9, 2002), available at http://www.icc-cpi.int/en_menus/icc/legal\% 20texts\%20and\%20tools/official\%20journal/Documents/RPE.4th.ENG.08Feb1200.pdf.

77. Rome Statute, supra note 1, art. 21(1)(b).

78. Id. art. $21(1)(\mathrm{c})$. The drafters compromised further by stating that "general principles of law derived by the Court from national laws of legal systems of the world include[s], as appropriate, the national laws of the States that would normally exercise jurisdiction over the crime ...."Id. Although such a reading might prevent harm to the accused under the nulla poena sine lege standard, in that the accused might have greater awareness of the illegality of an act under, for example, national or territorial jurisdiction of a particular state, the Conference of the ICC Statute "rejected the view of some delegations that the phrase 'including, as appropriate' should be replaced with 'especially'." COMMENTARY, supra note 24 , at 703 . Thus, the laws of the state that would normally exercise jurisdiction have no presumptive authority greater than other national laws of legal systems of the world.

79. Rome Statute, supra note 1, art. 21(2). 
caused by atrocity crimes.

Taking a transnational legal process approach, ${ }^{80}$ national representatives have in previous contexts adopted or recognized existing principles under international law norms, ${ }^{81}$ met in groups to discuss implementation of international law standards, ${ }^{82}$ and have pushed for the internalization of those standards within a transnational, supranational, or international structure. $^{83}$

The concern over restrictive standards undermining the object and purpose of the Rome Statute, and the principles of law the Statute supports, could be raised in the selection and prosecution of a number of cases and

80. Harold Hongju Koh describes the transnational legal process as having three phases: One or more transnational actors provoke an interaction (or series of interactions) with another, which forces an interpretation or enunciation of the global norm applicable to the situation. By so doing, the moving party seeks not simply to coerce the other party, but to internalize the new interpretation of the international norm into the other party's internal normative system. The aim is to 'bind' that other party to obey the interpretation as part of its internal value set. Such a transnational legal process is normative, dynamic, and constitutive. The transaction generates a legal rule, which will guide future transnational interactions between the parties; future transactions will further internalize those norms; and eventually, repeated participation in the process will help to reconstitute the interests and even the identities of the participants in the process. Harold Hongu Koh, Review Essay, Why Do Nations Obey International Law? The New Sovereignty: Compliance with International Regulatory Agreements by Abram Chayes and Antonia Handler Chayes, 106 YALE L. J. 2599, 2646 (1997) (emphasis added); see also Leila Nadya Sadat, The Nuremberg Paradox, 58 AM. J. CoMP. L. 151, 162 (2010) (describing "the existence of transnational legal processes that lead courts, especially, to adopt international norms," in the context of French adoption of the Nuremberg principles in prosecutions of crimes against humanity).

81. See, e.g., MANUAL OF THE LAWS OF WAR ON LAND (Oxford, Sept. 9, 1880), available at http://www.icrc.org/ihl/INTRO/140?OpenDocument (noting that the Institute of International Law "believes it is fulfilling a duty in offering to the governments a 'Manual' suitable as the basis for national legislation in each State, and in accord with both the progress of juridical science and the needs of civilized armies . . . [and, in not trying to add new law, the Institute] contented itself with stating clearly and codifying the accepted ideas of our age so far as this has appeared allowable and practicable." Id. at Preface (describing this facet of transnational legal process as interacting from a positivist (or objective law) perspective)).

82. See Robert O. Keohane, Jr., Institutional Theory and Realist Challenge after the Cold War, in Neorealism \& Neoliberalism 269 (David A. Baldwin ed., 1993) (describing this facet of transnational legal process as interpreting the standards in specific contexts through commissions or other institutions). This is an institutionalized perspective that eventually looks to the International Law Commission or its committees for guidelines as to the development of the ICC.

83. This could be described as a constructivist approach - determining the constitution of rules related to the identified norms, and allowing for the further implementation of norms through that construct. See John Gerard Ruggie, What Makes the World Hang Together? Neo-utilitarianism and the Social Constructivist Challenge, 52(4) INT'L ORG. 855, 871 (1988) (noting that "Constitutive rules define the set of practices that make up a particular class of consciously organized social activity - that is to say, they specify what counts as that activity."). 
for many reasons. One important area in which the conflict in rule-setting with regard to the definition of crimes has clearly arisen is the consideration of gravity as an indicator of admissibility on both qualitative and quantitative grounds. ${ }^{84}$

Considering the usurpation of authority a potential indicator of overall governmental incapacity or specific complicity with the alleged crime suggests an incentive for state governments to make every effort to retain authority over adjudication. ${ }^{85}$ In doing so, however, the state tribunals need not behave as though exercising powers delegated to the States by the ICC, and therefore limited to the interpretation of those powers by the ICC. Rather, to the extent the articulation of specific crimes by the ICC reflects jus cogens forbidding atrocity crimes,${ }^{86}$ the adoption and implementation by states of the ICC statute creates an opportunity for states to define the jurisprudence of international criminal law in conjunction with the ICC statute.

\section{The Decoupling of State Actors' Roles and Redoubling of a State Actors' Efforts}

The lack of transnational legal process is not the only obstacle to positive norm-setting on the national level. In addition, States Parties are failing to live up to their own obligation to act on two levels and with two purposes: on the national and international level; and with the dual purposes of 1) enforcing domestic norms and 2) informing and enriching international norms in the process.

The concept of jus cogens or "compelling law" that allows no derogation is a kindred spirit to the notion of le droit des gens, or "the law of people". described by French law professor and original member of the UN International Law Commission Georges Scelle. ${ }^{87}$ In Scelle's Précis du droit des gens, he cites to Montesquieu's definition that "Laws are

84. See, e.g., Ewald, supra note 43, at 371; see generally Schabas, supra note 4.

85. KLEFFNER, supra note 2, at 317-18 ("Complementarity bestows upon national proceedings the pedigree of 'willingness' and 'ability' when the Court determines that a case is inadmissible in accordance with Article 17(1)(a) to (c) of the Statute."); id. at 320 (discussing the "largely antagonist premise on which the regime of complementarity is based ... [where States] want to avoid the embarrassment that a declaration of admissibility would entail.").

86. In agreeing to the particular crimes included in the Rome Statute, some states noted that this would not create additional laws. See RESTATEMENT (THIRD) OF THE LAw OF FOREIGN RELATIONS OF THE UNITED STATES $§ 103$ (1965), cmt. K, Reporter's Notes 6; id. $\S$ 702 (listing state violations of peremptory norms).

87. See, e.g., Hubert Thierry, The Thought of Georges Scelle, 1 EUR. J. INT'L L. 193, 198 n.10 (1990) (using the "law of people" as opposed to the more typical translation "Law of Nations" clarifies the role of the individual as "the only genuine subject [] of international law."). 
necessary relationships which derive from the nature of things," to lead to the concept of a law of integration and progress leading to "objective law." ${ }^{88}$ Because this objective law conforms to social necessities, positive law that derogates from objective law - that fails to conform to those social necessities - becomes anti-legal, and may be rejected. ${ }^{89}$ Binding positive law gains its validity from the bundle of conditions necessary for the existence of a social fact, without which the social fact could neither come about nor persist. ${ }^{90}$ These purported causal laws that support social functioning are not necessarily enunciated as positive law, but are the basis around which legislators might construe and assess positive law. ${ }^{91}$

88. Id. at 199 (citing Georges Scelle, Precis du Droit Des Gens, 37 (Vol. I. 2008), for the concept that objective law develops from social reality). See also, Georges Scelle, Règles Générales du Droit de la Paix, in 46 ReCueIL DES COURS DE L'ACADEMIE DE LA HAYE 327 (1933) [hereinafter Scelle]:

Le droit objectif est l'ensemble des lois causales qui déterminent l'apparition, la permanence et le développement du fait social ... . La traduction normative de ces lois causales immanentes s'appelle le droit positif. Le droit positif n'est donc, par définition, que la transposition sur le plan normatif des lois causales d'une société. Cette transposition peut être d'ordre coutumier ou instinctive ; d'ordre législatif, réglementaire ; d'ordre autocratique ou conventiennel .... Il se peut, il est même fréquent, que le droit positif diffère et s'écarte du droit objectif, que la norme sociale diffère de la loi causale, soit parce que l'infirmité de l'agent coutumier ou législatif empêche le droit objectif d'être totalement perçu, soit parce que les insuffisances techniques de l'organisation sociale empêchent une totale juxtaposition du système de lois et du système de normes. Cependant, par une hypothèse nécessaire, il faut considérer comme acquis, jusqu'à preuve contraire, qu'il y a coïncidence exacte entre l'un et l'autre, car sans cela le droit positif ne pourrait pas avoir de valeur obligatoire. La validité (geltung) du droit positif réside, en effet, dans sa concordance avec le droit objectif. ("Objective law is the conglomeration of causal laws which determine the appearance, permanence, and development of social facts .... The normative translation of these self-made causal laws is positive law. Positive law, then, is only, by definition, the transposition of a society's causal laws onto a normative plane. This transposition can be either through custom or instinct; through a legislative or regulatory means; from a despotic or conventional society ... . It can happen, it's even frequent, that positive law differs and separates from objective law, that the social norm differs from the causal law, either because a weakness in the customary or legislative agent prevents the law from being totally perceived, or because insufficient technique in the social organization prevents a total juxtaposition of the system of norms and the system of laws. However, as a necessary hypothesis, one must take for given, until the opposite is proven, that the two exactly coincide, because otherwise positive law could have no obligatory value. The validity of positive law rests, in effect, in its agreement with objective law.").

Id. at 348-50.

89. Thierry, supra note 87, at 199.

90. Id. (A rule not necessary toward the existence of a social fact would therefore not be "objective law.").

91. Id. at 198. 
In the context of international, supranational, and extra-national relations, actions taken by state actors "are by nature international, since their goal, and result, is to realize this phenomenon of [legal monist] solidarity or international relations, and they are, and can only be, accomplished in conformity to international norms. ${ }^{, 92}$ While the state actors could, therefore, act from a national or international perspective, and where there exist no specifically international leaders or agents, the state leaders and agents that stand in for the specifically international leaders/agents take on a "double role." 93 They are national agents and leaders when they function in the state juridical order; they are international agents and leaders when they act in the international juridical order. ${ }^{94}$ Scelle describes this dédoublement fonctionnel - as the fundamental law of the uncoupling of functions, but most describe it as "role splitting."

In the context of complementarity before the ICC, some have posited that instead of having to uncouple a national and international function, the national court and the international court exist in a relation of role concurrence - in the first instance, the national court may take jurisdiction over the trial of an alleged perpetrator of an atrocity crime, but the international court will exercise its role in prosecuting the perpetrator when the national court's failure to prosecute activates the international court's concurrent jurisdiction. ${ }^{96}$ Because they both may take responsibility for the

92. Scelle, supra note 88 , at 358 ("[I]l reste que ces fonctions sont par nature internationales, puisqu'elles ont pour but et pour résultat de donner satisfaction à un phénomène de solidarité ou à des rapports internationaux et qu'elles sont et ne peuvent être accomplies que conformément aux normes internationales.").

93. See Antonio Cassese, Remarks on Scelle's Theory of "Role Splitting" (Dédoublement Fonctionnel) in International Law, 1 EUR. J. INT'L L. 210, 212 (1990).

94. Id.

95. Id. at 214

96. Some have referenced such an obligation as "role concurrence," or the simultaneous protection of important legal values of the international community and the national legal order. KlefFNeR, supra note 2, at 32 (citing Otto Triffterer, Preliminary Remarks: The Permanent International Criminal Court-Ideal and Reality, in COMMENTARY ON THE ROME Statute of the International Criminal Court-Observers' Notes, Article by ARTICLE 26-28 (Otto Triffterer ed., 1999). While the concept of role concurrence is, indeed, a departure from Scelle's construct, it would appear less a departure in translating dedoublement as uncoupling - that is, each state that acts in the international community necessarily acts through its organs in both domestic and international spheres. Where law exists in the international sphere and international courts do not exist or are otherwise unable to implement that law, the courts of the state act to fulfill the obligations of the state. Because such courts are applying binding international standards on behalf of the state, the courts must uncouple the two roles - that of state court with that of international court. The court doing otherwise would be anti-legal, undermining an international rule of law. See, e.g., Scelle, supra note 88 , at 657 :

If the connection of juridical situations puts into play the competence of government actors of other states, or actors with concurrent responsibility, the role of government actors careful to procure the realization of law in a 
prosecution, the international and national courts would share the role of preventing and punishing atrocity crimes. ${ }^{97}$

The potential for shared jurisdiction may deviate from the notion of a concurrent role as opposed to a shared role. To the extent that national courts have a responsibility to vindicate supranational or meta-national ${ }^{98}$ harms arising from atrocity crimes, the role is certainly not dissimilar from that exercised by the ICC - both the ICC and national courts are prosecuting alleged perpetrators of atrocity crimes. Realistically, however, crimes vindicated by the ICC must be limited qualitatively and quantitatively by virtue of limited jurisdiction and resources, as well as concerns for sovereign control over criminal justice matters. ${ }^{99}$ As such, the national courts have an opportunity to revisit the goal of what Scelle would refer to as the underlying "objective law," to determine which cases can and should be prosecuted by the national courts, even where the ICC would elect not to prosecute or would find the case inadmissible for lack of

recognized interstate milieu will consist of a coercive act exercised on their governmental actor colleagues to obtain from them the regular utilization of their competences.

See also id. at 667 :

We are preoccupied with intervention only in international relations. But we know as well that there's no divider between an internal juridical order and the international juridical order: the extent of the latter determines the structure of the former, and when the competence of subjects of law, including nationals in interstate commerce, are covered by an international norm, the application of this norm stems from international law, even in relations between the governing and the governed, immediate subjects of the law of people.

97. This shared responsibility echoes the logic of the Responsibility to Protect, in that the state would have primacy over the international community, but the international community may need to act to put an end to crimes against humanity (including the crime of persecution through ethnic cleansing), genocide, or war crimes. See 2005 World Summit Outcome, G.A. Res. 60/1, ff 138-39, U.N. Doc. A/RES/60/1 (Sept. 15, 2005) (United Nations General Assembly reaffirming World Summit Outcome on Responsibility to Protect, available at http://www.globalr2p.org/media/files/wsod_2005.pdf [hereinafter 2005 World Summit Outcome]; see also Gareth Evans, Crimes Against Humanity and Responsibility to Protect, in Forging a CONVENTION for CRIMEs AGaINST Humanity 2 (Leila Nadya Sadat, ed. 2011); see generally Charity, supra note 28.

98. "Meta-national" refers to the community of peoples, and the joint interest of the nation of nations, as opposed to any smaller group that may have bilateral or other smaller group commonalities at a level hierarchically superior to the nation (supranational). See KLEFFNER, supra note 2, at 316 (claiming state promotion of matter from a national to the international realm ensures and protects "meta-national values, such as peace, human dignity and the needs of all mankind," in describing gradual development toward a "universal" law of the world community).

99. Schabas, supra note 4 , at 542,544 (noting that there are simply not enough resources for international criminal tribunals to aspire to prosecute all international crimes within their jurisdiction, and that the Office of the Prosecutor of the International Criminal Court explains the choice of situations selected by referencing the "gravity" of the situation). 
gravity. ${ }^{100}$ The role of the national court is, in the first instance, a greater role, because it may act without the strictures and limitations of the Rome Statute to prosecute perpetrators in a manner that effectively protects its populations prior to the ICC considering admissibility under a complementarity regime.

None of this suggests that national courts should elect to use substantially different national standards over international standards; rather, because of the deontological differences in the international and domestic tribunals and the fact that international standards require different duties of international courts than of national courts, the use of international standards in the investigation and punishment of crimes against humanity by courts should and must be done differently in domestic tribunals than in international tribunals. ${ }^{101}$ Even in approaching the same end, the complementarity regime and the history of the development of the atrocity crimes demand a different approach of national courts.

\section{Why Negative Complementarity Fails to Offer Sufficient Incentives to Ensure Enforcement}

Many commentators have considered the utility of the ICC from the perspective of negative complementarity. ${ }^{102}$ In considering the object and purpose of the Rome Statute, negative complementarity is the ability of the ICC to initiate an investigation only after the state that would otherwise have jurisdiction has failed to do so. ${ }^{103}$ It is imperative to look at the goal of the international community and the roles of the state and the ICC in that process. The goal of the international community is the protection of human lives from the harms of aggressive war, genocide, crimes against humanity, and war crimes. However, these goals are not achieved when the ICC and the national courts and governments working complementary to each other, are on somewhat independent spheres under a negative complementarity framework.

One theory supporting the framework of negative complementarity focuses on the principle of domestic interest in several ways: first, in promoting a positive world perception of the state's judiciary and its

100. One might reference this as a "redoublement fonctionnel," or a functional redoubling of the state actor's efforts - exercising a metanational responsibility that the state could have chosen to opt out of, for the purpose of vindicating a core international responsibility.

101. Cassese, supra note 93, at 213.

102. See, e.g., Alexander K.A. Greenawalt, Complementarity in Crisis: Uganda, Alternative Justice, and the International Criminal Court, 50 VA. J. INT'L L. 107 (2009); William A. Schabas, Complementarity in Practice: Some Uncomplimentary Thoughts, 19 CRIM. L.F. 5 (2008); Kevin Jon Heller, The Shadow Side of Complementarity: The Effect of Article 17 of the Rome Statute on National Due Process, 17 CRIM. L.F. 255 (2006).

103. Rome Statute, supra note 1, art. 17. 
general capacity and support for the rule of law over anti-legal government acts or actors; ${ }^{104}$ second, the state's interest in maintaining its sovereignty over matters arguably within its domestic sphere, as opposed to yielding sovereignty over certain criminal matters to an extra-national court; and third, the application of the underlying laws for which the extra-national court complements the state apparatus.

These justifications for relying on a negative complementarity framework are predicated on the state's negative reaction to public censure or to an extra-national sense that an act by the state breaches an international obligation. Negative complementarity presumes that the state might take action to avoid its control over a situation being undermined, and that the state's reaching an agreement with the international community on the extent of the underlying laws - whether ultimately under state or international jurisdiction - will somehow undercut state interests. Negative complementarity at its heart suggests that the state will do all in its power to prevent the assertion of authority by the complementing body ${ }^{105}$ and, therefore, assumes that prosecution of many levels of alleged war criminals will take place at the state level in order to prevent extra-national control and influence.

On the international level, negative complementarity also assumes that the ICC will do all in its power to prosecute an alleged atrocity crime perpetrator if the state will not. However, as previously discussed, from the perspective of limited resources, prosecutorial discretion, and a lack of norm-setting guidance toward a scope broad enough to encompass such crime, the ICC has not thus far lived up to its potential in this regard.

More importantly, and not considered fully in the negative complementarity discourse, the role of the national tribunal can and should be broader than that of the international tribunal, where the state is willing and able to pursue a case against an alleged perpetrator. History shows that the development of the laws on atrocity crimes has been most successful when leaders were communicating with each other and, unfortunately, when their populations were impacted by the atrocities. ${ }^{106}$ While the

104. See, e.g., KLEFFNER, supra note 2, at 317 ("There is no need for international adjudicative fora if, and when, national courts can adequately achieve effective adjudication ..."Id. (citing to the requirement in the U.N. Secretary-General, Rep. of the Secretary Gen. on the Establishment of a Special Ct. for Sierra Leone, U.N. Doc. S/2000/915 [10] (Oct. 4 2000 ), that local courts in Sierra Leone acquire additional capacity prior to the determination of the international community's referring matters back to the state by limiting the longevity of the Special Court, implicitly recognizing a lack of capacity at the state level)).

105. KLEFFNER, supra note 2, at 320 ("for the first time in the history of international criminal law, State Parties have agreed ex ante that this failure [to adequately investigate and prosecute core crimes within its jurisdiction] will entail a concrete legal consequence: States forfeiting the claim to exercise jurisdiction, including over their own nationals and officials.").

106. See deGuzman, supra note 12, at 20-22 (arguing that the development of laws 
international court and the national court may have the same ultimate goal of responding to an objective law relating to the prevention of atrocity crimes, the roles of the courts differ. One failure of the international tribunal is the institutionalization of its voice and the impact of its interpretation. The example of the prosecution of Bosco Ntaganda illustrates the point.

\section{DEVELOPMENT OF INTERNATIONAL LAWS CAPABLE OF DEALING WITH ATROCITY CRIMES}

To understand the development of international criminal law's focus on atrocity crimes through a transnational legal process lens, we must start where the nations focusing on atrocities are interacting. By looking at responses to wars, starting in the mid-nineteenth century, we can see the slow, but continuing, process of interaction, interpretation, and internalization of the social mitigation of war crimes, aggression, and crimes against humanity. ${ }^{107}$

This series of negotiations, accords, and conventions reveals two important lessons for current efforts at supporting a broad jurisdiction for international criminal justice mechanisms. First, the transnational discourse has been and can be an effective means of building state-level consensus as to norm-setting. From a transnational legal process perspective, these postconflict interactions among states with regard to the rights and obligations of occupying powers in late nineteenth century and twentieth century Europe offer important parallels to our contemporary questions as to how state-level discourse can act as a norm-setting mechanism vis-à-vis the rights and obligations of international tribunals.

Second, the history reveals a striking pattern that persists today of an initial post-conflict push toward international criminal norms that would allow for broad prosecution of war crimes, only to have state-level insecurities lead to the narrowing of the scope of the international legal standards, a smaller number of prosecutions, and the resulting diminution of the initially sought-after accountability and deterrent effect.

addressing atrocity crimes stemmed from atrocities suffered during World War II, and that subsequent development occurred after the mass atrocities occurring in Rwanda and the former Yugoslavia).

107. See generally DieTRICH SCHINDLER \& JiRI TOMAN, THE LAwS OF ARMEd CONFLICTS (Martinus Nijhoff, Dordrecht, eds. 1988); see generally International Humanitarian Law Treaties \& Documents - Methods and Means of Warfare, ICRC.ORG, http://www.icrc.org/ihl (last visited May 12, 2013) (reflecting much of the interactions between the states). 


\section{A. The 1874 Brussels Conference $e^{108}$}

Following the Franco-Prussian War, fifteen European states gathered to discuss the laws of war, some of which had been violated during the course of the relatively brief, but bloody, conflict. ${ }^{109}$ In considering a transnational legal process approach, the interaction of the states most affected by the war raised questions as to the proper approach to the treatment of war crimes. For example, the states had to address whether an occupying power such as Prussia had the right to defend itself against guerilla warfare by the militia-like francs-tireurs, ${ }^{110}$ and the mass conscription of French citizens who were not regular soldiers, or whether these French citizens who acted in defense of their country deserved prisoner-of-war status.

The fifteen states utilized the code developed during the United States Civil War by Francis Lieber ${ }^{11}$ in an attempt to develop an "International Declaration concerning the Laws and Customs of War." By building on the Lieber Code, which in turn relied on a number of seventeenth and eighteenth century European laws of armed conflict theorists, the leaders hoped to set stricter guidelines for warfare and post-conflict accountability mechanisms, as Lieber's code purported to be "strictly guided by the principles of justice, honor, and humanity."112

The Lieber Code required that soldiers show more discipline during war than civilians. Soldiers violating the Lieber Code might face the punishment of death, "or such other severe punishment as may seem adequate for the gravity of the offense." 113 The penal codes applicable to soldiers during combat would "not only punish [soldiers] as at home, but in

108. See Yves Sandoz, The History of the Grave Breaches Regime, 7 J. INT'L Crim. JusT. $657,663-64$ (2009). The article gives an excellent description of the development of grave breaches of the laws of war. For more on the resolutions undertaken by the states parties to the 1874 Brussels Conference on August 27, 1874, see International Humanitarian Law Project of an International Declaration Concerning the Laws and Customs of War. Brissels, 27 August 1874, available at http://www.icrc.org/ihl.nsf/INTRO/135?OpenDocument.

109. For a cogent analysis of the conflict, see GEOFFreY WaWro, THE Franco PruSSIAN WAR (Cambridge 2003).

110. Francs-tireurs, literally, "free shooters," were men living in eastern France who trained with high quality rifles and were sometimes affiliated with the French army. When franc-tireurs were captured, Prussians did not wish to treat them as captured enemy soldiers because the free-shooters did not dress in uniform or fight with an organized group.

111. The code was entitled, "Instructions for the Government of Armies of the United States in the Field" but is generally referred to as the Lieber Code. See Ernest Nys, Francis Lieber-His Life and His Work: Part I, 5 AM. J. INT'L L. 84, 86 (1911) (describing the contributions of Lieber to the internationalization of the laws of war).

112. Sandoz, supra note 108, at 660; See also Francis Lieber, Instructions for the Government of the Armies of the United States in the Field, art. 4 (Apr. 24, 1863), available at http://www.icrc.org/ihl/INTRO/110 [hereinafter Lieber Code].

113. Sandoz, supra note 108, at 661-62; see also Lieber Code, supra note 112, art. 44. 
all cases in which death is not inflicted, the severe punishment shall be preferred." violation of rights in the Franco-Prussian War allowed the parties to develop a shared standard and joint interpretation of the Lieber Code and of the laws and customs of war more generally. The transnational nature of this enterprise marked a significant advance in the international discussion of the prosecution of war crimes.

The parties adopted the International Declaration concerning the Laws and Customs of War but did not create a binding convention. Thus, they did not bind themselves through positive law. Notwithstanding the failure to create a convention, one delegate suggested that states coordinate their internal legislation to ensure equal punishment for those violating the rules of war. ${ }^{115}$ Perhaps due to a reluctance to cede a significant responsibility with regard to criminal justice to a larger decision-making body, ${ }^{116}$ this suggestion was not acted upon, leaving the parties' interpretation on the table at the end of the Brussels Conference.

Regardless of the reason, these countries had come together following a conflict to consider parameters to behaviors of belligerents during time of war, seeking to prevent the negative consequences of other states' overstepping those parameters. In so doing, the states came much closer to holding themselves accountable and created a framework from which to work in the future to define limits of warfare.

\section{B. The Oxford Manual of 1880}

Notwithstanding the failure of the Brussels Declaration to be made into a convention, the Lieber Code was not without impact. In 1880, the Institute of International Law ${ }^{117}$ adopted its "Manual of the Laws of War on Land." ${ }^{118}$ Drawing principles from the Lieber Code and the 1874 Brussels Conference, the Manual stated that where the violation of the laws of war

114. Sandoz, supra note 108, at 662; see also Lieber Code, supra note 112, art. 47.

115. Sandoz, supra note 108 , at 663 .

116. Id.

117. The Institute of International Law (or Institut de Droit International) is a nongovernmental body formed in 1873 to develop the standards of international law and promote human rights. See History, INSTITUTE OF INTERNATIONAL LAw, http://www.idiiil.org/idiE/navig_history.html (last visited May 16, 2013). For its influential work on developing international law, it was awarded the 1904 Nobel Peace Prize.

118. The Laws of War on Land. Oxford, 9 September 1880, (Sept. 9, 1880), available at http://www.icrc.org/applic/ihl/ihl.nsf/INTRO/140?OpenDocument\&redirect=0. The preface to the Manual notes that it does not seek an international treaty laying out the laws of war, which the authors acknowledge "might perhaps be premature or at least very difficult to obtain," but that the Manual "strengthens the discipline which is the strength of armies; it also ennobles their patriotic mission in the eyes of the soldiers by keeping them within the limits of respect due to the rights of humanity." Id. at Preface. 
are at the same time offenses against the general criminal law, the perpetrator should be tried and punished by the courts of the injured adversary: "the offending parties should be punished, after a judicial hearing, by the belligerent in whose hands they are ... [with the ] offenders against the laws of war [being] liable to the punishments specified in the penal or criminal law," when the person of the offender could be secured. ${ }^{119}$ The articulation of this standard in 1880 , which would be repeated in a second Oxford Manual of $1913,{ }^{120}$ would have a strong effect on the rules agreed to by the victorious powers that would be able to claim almost thirty years of recognition of the standard prior to seeking to apply it. As states sought consensus on the legal rights of states to prosecute war criminals, even those concerned with ex post facto laws recognized the right of the injured belligerent to prosecute the captured enemy under its own laws, the standard articulated by the International Law Institute's 1880 and 1913 Oxford Manuals. ${ }^{121}$

\section{The Hague Conference of 1899}

Twenty-five years after the Brussels Conference, Europe and other states again gathered to reach a consensus in regards to the regulation of the laws and customs of war. ${ }^{122}$ In June 1899, the Hague Diplomatic Conference revisited topics covered in the Brussels Declaration, including the legality of acts between occupying powers and citizens of the occupied state.

Belgium, a smaller nation only recognized in 1830 , was concerned that its sovereignty might be overrun by transnational norms created by more powerful states. It was particularly concerned that rights recognized in the Brussels Declaration granted too great a power to an occupying force and forbade the recognition of civilians as lawful combatants when fighting

119. James W. Garner, Punishment of Offenders Against the Laws and Customs of War, 14 AM. J. INT'L L. 70, 71 (1920) (citing ANNUAIRE DE L'INSTITUT [DE DROIT INTERNATIONAL], $174(1881-1882))$.

120. See Manual of the Laws of Naval War (Aug. 9, 1913), available at http://www.icrc.org/applic/ihl/ihl.nsf/INTRO/265?OpenDocument\&redirect=0 (noting the comparable application of laws of land warfare (Article 79), but also noting that prisoners of war are "subject to the laws, regulations, and orders in force in the navy of the State in whose power they are." (Art. 73)).

121. See, e.g., the acceptance of national tribunals to try combatants following World War I factoring in both the Commission Report (see infra note 135, at 121), and the Reservations of the United States (14 AM. J. INT'L. L. 95, 129 (1920)).

122. Czar Nicholas II called the conference with the intention of "seeking the most effective means of ensuring to all peoples the benefits of a real and lasting peace, and, above all, of limiting the progressive development of existing armaments." See Final Act of the International Peace Conference, The Hague, July 29, 1899, available at http://www.icrc.org/ ihl.nsf/INTRO/145?OpenDocument. 
an occupying force. ${ }^{123}$ As opposed to codifying such a standard, the Belgian delegate argued, "In my opinion, there are certain points which cannot be made the object of a convention, and which would be better to leave as they stand today, under the rule of the tacit and common law which results from principles of the law of nations."

In interpreting the language of the Brussels Declaration, the Belgian delegate recognized that the agents of the various states were interpreting and, potentially, codifying a standard that the representatives of smaller states could not support, because of the power recognized in states more likely through military strength (and in recent past experience) to occupy those smaller states. ${ }^{125}$ The Belgian delegate reframed the question so that the Conference would not decide the legality or illegality of a particular act during war; rather, the Conference would determine whether new law would be needed as part of the Hague Convention Respecting the Laws and Customs of War on Land (later known as the Hague Conventions), limiting harms that could be perpetrated by either party. ${ }^{126}$

Fyodor Fyodorovich Martens served as a delegate from Russia, one of the Great Powers, which supported the principles recognizing rights in occupying powers. When the parties had reached an impasse as to the balance of power between international and domestic control of war crimes issues, Martens provided the following clause (later known as the Martens Clause) for adoption:

Until a more complete code of the laws of war has been issued, the High Contracting Parties deem it expedient to declare that, in cases not included in the Regulations adopted by them, the inhabitants and the belligerents remain under the protection and the rule of the principles of the law of nations, as they result from the usages established among civilized peoples, from the laws of humanity, and the dictates of the public conscience. They declare that it is in this sense especially that Articles 1 and

123. For a discussion of the power dynamics between the delegations during the 1899 Hague Conference, see Cassese, infra n. 124.

124. Cassese, The Martens Clause: Half a Loaf or Simply Pie in the Sky?, 11 Eur. J. INT'L L. 187, n.11 (2000) (citing Conférence Internationale de la Paix, La Haye 18 Mai-29 Juillet 1899, Troisième Partie (1899) at 111 ("A mon avis, il y a certains points, qui ne peuvent faire l'objet d'une convention et qu'il vaudrait mieux laisser comme aujourd'hui, sous l'empire de cette loi tacite et commune qui résulte des principes du droit des gens.")).

125. Id. at 193-98.

126. Id. 


\section{2 of the Regulations must be understood. ${ }^{127}$}

The Belgian delegation supported this limiting language as a major check on potential occupying powers: "[ $\mathrm{t}] \mathrm{omorrow}$, as today, the rights of the conqueror, far from being unlimited, will be restrained by the laws of public conscience (conscience universelle) and not one country, not one general would dare to transgress them, since that would submit oneself to banishment from the civilized nations." 128 Notwithstanding arguments over the accuracy of this characterization, the Conference sidestepped the specific dispute and reached agreement on a broader point. The States Parties to the Hague Convention of 1899 internalized not the right to engage in patriotic resistance to an occupying force, nor a standard for the applicable legal authority held by an occupying power, but the legal norm recognizing the place of laws of humanity and dictates of public conscience alongside the (non-conflicting) terms of the treaty. ${ }^{129}$ By shifting the interaction - the question of what law the parties sought to reach agreement on - the interpretation and internalization of the norm became much broader, focusing on the process for legal interpretation rather than the primary law that would directly recognize authority in occupiers. ${ }^{130}$

127. Id. at n.l. This component of the 1899 and 1907 Hague Conventions Respecting the Laws and Customs of War on Land, known as the Martens clause after the Russian diplomat who recommended it, may do no more than to extend to those engaging in combat as francstireurs the protections recognized for other lawful combatants, if it goes even that far. See, e.g., id. at 187-216 (arguing that custom did not permit attacks on the occupying force and would not have protected francs-tireurs, but Martens used the somewhat vague language of the clause to appease smaller countries while not affecting the responsibilities of the great Powers). Nevertheless, the reasoning allowed for under the Martens clause calls for the application of recognizable but not fully enunciated rules over a variety of circumstances not yet fully developed. Again, it may be of interest that the smaller states, such as Belgium, are looking to the protection of individuals (under the droit des gens) as opposed to the rights of states.

128. Id. at n.29 (citing Conférence Internationale de la Paix La Haye 18 Mai-29 Juillet 1899, Troisième Partie (1899) at 153) ("Demain comme aujourd'hui les droits du vainqueur, loin d'être illimités, seront restreints par les lois de la conscience universelle et pas un pays, pas un général n'oserait les enfreindre, puisque ce serait se mettre au ban des nations civilisées.").

129. Indeed, Cassese references the speech made by Martens after Martens tabled his proposal of the clause: "Il . . . faut se rappeler que ces dispositions [on lawful combatants and mass conscription (lévée en masse)] n'ont pas pour objet de codifier tous les cas qui pourraient se présenter." ("We must recall that the object of these clauses is not to codify every eventuality that could present itself."). Id. at n.18. Despite Cassese's (and Martens') view that the clause was meant to deal only with these two aspects of guerilla warfare, the defense of the limitations on the clause make the very point raised by the Belgian delegate the smaller states could continue to look to custom and general principles in response to the overwhelming force of an occupying power.

130. See Legality of the Threat or Use of Nuclear Weapons, Advisory Opinion, 1996 I.C.J. 375, 408, (dissenting opinion) (arguing that "the basic function of the Clause was to 
Although the 1899 Hague Convention called only for state liability for compensation and not for criminal sanctions, the normative effect of the Martens Clause's adoption allowed for a second iteration in the 1907 Hague Convention Respecting the Laws and Customs of War on Land, and the adoption of language at that point reflected a belief in the legality of reliance as legally cognizable the public conscience and laws of humanity moving forward in interpreting lawful conduct in times of armed conflict between states. ${ }^{131}$

\section{The 1919 Treaty of Versailles}

Following World War I, the most powerful nations in Europe convened again to continue their discussions on how to resolve the issue of concurrent powers and the allocation of prosecutorial power to the international level. The transnational legal process that led to the recognition of liability for violations of the laws of war in the Hague Conventions of 1899 and 1907 were coupled with questions of individual culpability that came to the forefront during the Peace Conference of 1919.

The Commission of Responsibility of Authors for the War (the Commission of Responsibilities, or the Commission) was tasked by the Peace Conference to deal with questions of war crimes and international accountability. ${ }^{132}$ The Commission investigated the causes of war and evaluated the ability of the several Allied powers to create a tribunal appropriate to try offenders against the laws and customs of war. ${ }^{133}$ It distinguished this responsibility from that of the development of an

put beyond challenge the existence of principles of international law which residually served, with current effect, to govern military conduct by reference to the 'principles of humanity and ... the dictates of public conscience."') One should also note Martens' own investment in, and his reminder to his colleagues regarding, the Conference's successfully codifying some of the standards the Brussels Declaration had failed to codify. Czar Alexander II had convened the 1874 Brussels Conference, and Czar Nicholas II convened the 1899 Hague Conference, such that Martens reminded his colleagues that the failure of the diplomatic community to agree on specific treaty rules for a second time would show the military that diplomats could not fashion rules regarding the laws and customs of war, leaving the military free to interpret the laws of warfare as they pleased. See Cassese, supra note 124 , at 195 .

131. Although Cassese argues that Martens' references in the clause may have been a political expedient to appease the Belgians, Martens' belief in a limited natural law depiction of human rights foreshadows the "objective law" view of Scelle: "These [human] rights flow from the nature and from the conditions of humanity and so cannot be created by legislation. They exist in themselves." [Ces droits [de l'homme] découlent de la nature et des conditions de l'humanité et ne peuvent donc pas être créés par la législation. Ils existent par euxmêmes.] Cassese, supra note 124, n. 45 (citing Martens, Traité de droit international, vol. I, at $14(1883-87))$.

132. See Paris Peace Conference, Violations of the Laws and Customs of War: Reports of Majority and Dissenting Reports American and Japanese Members of the Commission of Responsibilities, 1-2 (1919). Foreign Relations of the United States, vol. III, 203-05 (1919).

133. Id. 
international tribunal and truth-gathering organization, a job believed to be better left to historians.

As noted previously, the 1907 Hague Convention restated and reiterated the 1899 Martens Clause to call for a broader reading of positive law as expressed through principles and the laws of humanity, beyond the written word articulated in the codification completed during the 1899 and 1907 Conferences. The continued interaction among institutional actors, such as other delegates who accepted the terminology of and purpose behind the Martens Clause, allowed for its repeated use through the 1919 Peace Conference and its internalization by representatives of States Parties. ${ }^{134}$ It was of particular import to the Commission that during the 1907 negotiations, the German representative had taken a stance on the importance of international principles as guiding state actions. Rather than focus on formulating specific language for each eventuality, that representative had stated that certain acts would not be taken by the German Navy, not because of the codification undertaken by the Conference, but because such actions would be contrary to the unwritten law of humanity. ${ }^{135}$

That the German Navy used submarine mines during World War Ithe very act that the German representative had stated need not be specifically forbidden by treaty ${ }^{136}$ — was not lost to the participants in the 1919 Peace Conference. The Commission appeared to take particular offense that "those Powers . . . a short time before had on two occasions at The Hague protested their reverence for right and their respect for the principles of humanity," had fully reversed position and committed those very acts only a decade later. ${ }^{137}$

The understanding that, on some level, nations had accepted the idea of a transnational unwritten law of humanity allowed the commission to decide that "the public conscience insists upon a sanction which will put clearly in the light that it is not permitted cynically to profess a disdain for the most sacred laws and the most formal undertakings." the desire was for an international sanction against Germany's war crime,

134. Id.

135. See Commission on the Responsibility of the Authors of the War and on Enforcement of Penalties, Report Presented to the Preliminary Peace Conference (Mar. 29, 1919), 14 AM. J. INT'L. L. 95, 117-18 (1920) [hereinafter Commission Report]; see also id. n. 65 (citing the declaration of Baron Marschall von Bieberstein to the Hague Conference of 1907: "Military operations are not governed solely by stipulations of international law. There are other factors. Conscience, good sense, and the sense of duty imposed by the principles of humanity will be the surest guides for the conduct of sailors, and will constitute the most effective guarantee against abuses. The officers of the German Navy, I loudly proclaim it, will always fulfill in the strictest fashion the duties which emanate from the unwritten law of humanity and civilization.").

136. See id.

137. Id. at $117-118$.

138. Id. at 118 . 
the Commission was frustrated by the fact that the Hague Conventions had not set up a mechanism for the investigation and prosecution of a premeditated war of aggression. ${ }^{139}$ Instead, the Commission was only able to recommend, based on the gravity of the outrages upon the principles of the law of nations and upon international good faith, that certain acts "be the subject of a formal condemnation by the Conference," and that "for the future penal sanctions should be provided for such grave outrages against the elementary principles of international law." 140

Due to past interactions and the development of standards over the course of the previous half-century, the Commission's treatment of laws and customs of war and the laws of humanity could be, and was, much broader than its treatment of aggressive war. The Commission concluded that "[a]ll persons belonging to enemy countries, however high their position may have been, without distinction of rank, including Chiefs of States, who have been guilty of offences against the laws and customs of war or the laws of humanity, are liable to criminal prosecution."141 This marked a remarkable shift since a decade ago, there was reluctance in putting into place international tribunals to prosecute war crimes.

The Commission went even further, not limiting its recommendations with regard to international criminal prosecution to only those actually committing war crimes. In addition to the parties culpable for breaches of the laws of humanity, the Commission report added responsibility for those who failed to prevent violations of the laws or customs of war, which included some of the highest ranking military leaders and officials of the German government. ${ }^{142}$

During the course of the war, politicians and lawyers had called for the punishment of not just the immediate perpetrators but also of those with some degree of command responsibility. ${ }^{143}$ However, at the war's end, all

139. Id. (stating that a suddenly declared war under false pretexts

is conduct which the public conscience reproves and which history will condemn, but by reason of the purely optional character of the institutions at The Hague for the maintenance of peace (International Commission of Inquiry, Mediation and Arbitration) a war of aggression may not be considered as an act directly contrary to positive law, or one which can be successfully brought before a tribunal such as the Commission is authorized to consider under its terms of reference.).

140. Id. at 120. Again, the Commission considers the gravity of the outrages on the principles of international law or the law of nations as creating sufficient reason for future penal action.

141. Id. at 117 .

142. Id. at 121 .

143. See Garner, supra note 119, at 88-89 (citing 39 Revue Pénitentiaire 457 (1915) (according to Professor Weiss of the Law Faculty of the University of Paris, "I think . . . that not only the direct immediate offenders should be held responsible, but that we must go to the top; we must pass over the heads of the primary offenders, to the chiefs, to those of whom the soldiers and officers have been only the servants and valets.")). 
parties were waiting to see whether the international community would maintain the will to actually prosecute that broad range of individuals. ${ }^{144}$ Some noted that Kaiser William II had instigated the war and believed his stepping down and trial would be good for international justice and morality, and would also benefit the German people in terms of having an international reckoning for a key player in starting the war. ${ }^{145}$ The Commission held firm in its recommendation for a broad reach of potential war crimes culpability, encouraging its application for the first time to political leaders as well. ${ }^{146}$

Despite the strength of the Commission report, there were some doubts as to the wisdom of allowing international prosecution of war criminals. Even among the Allies in favor of the Commission report, some nationals questioned the logic of this submissive sovereignty - an international court may be prone to engage in overreach in making those decisions relating to imprisonment that were typically within the purview of the sovereign. ${ }^{197}$ Respected scholars were incredulous at the idea a sovereign would allow international tribunals of third states or enemy states to judge deeds typically left to the national courts. ${ }^{148}$

144. See, e.g., James F. Willis, Prologue to Nuremberg: The Politics and DiPlomacY OF PUNISHING WAR CRIMINALS OF THE FIRST WORLD WaR 51 (Greenwood Press 1982)(citing France's statement to Germany of October 4, 1918: "Conduct which is equally contrary to international law and the fundamental principles of all human civilization will not go unpunished .... The authors and directors of these crimes will be held responsible morally, judicially, and financially. They will seek in vain to escape the inexorable expiation which awaits them.").

145. See, e.g., id. at 38 (noting former U.S. President Howard Taft stating, "William was behind it all the time," and former U.S. Ambassador to Great Britain Joseph Hodges Choate hoping the war would "put an end to this Imperial Dynasty and give the people of Germany a chance.").

146. See Commission Report, supra note 135, at 116-17.

147. See Harry D. Gould, The Legacy of Punishment in International Law 16 (Palgrave MacMillan ed. 2010) (discussing sovereignty as the contrapositive to punishment in defining sovereignty as that which exists above punishment).

148. See Garner, supra note 119 , at $71, \mathrm{n} .2$, (quoting a speech from Professor Louis Renault, 1907 Nobel Peace Laureate and participant for France in the 1899 and 1907 Hague Peace Conferences, in which Renault was asked about the enforceability of a provision in a treaty of peace requiring delivery of principal offenders against the laws of war to triers outside of the defendants' nations:

I do not see how a government, even if conquered, could consent to such a clause; it would be the abdication of all its dignity; moreover, almost always, it is upon superior order that infractions on the law of nations have been committed. I have found the proposal excessive, though I understand the sentiment that inspired it. I cite it because it shows well to what point men, animated by justice and shocked by what has taken place, desire that the monstrosities of which French and Belgians have been victims should not go unpunished. 
Despite these concerns, the Commission suggested two mechanisms of prosecution. First, each belligerent would have the power to set up, or use from its current system, an appropriate domestic trial venue that would enforce international norms. ${ }^{149}$ Second, the Peace Conference could create a high tribunal to try special cases, including (1) defendants belonging to enemy countries that have committed outrages against civilians and soldiers of several Allied nations; (2) persons in authority whose orders affected the conduct of operations against several of the Allied armies; (3) all civil or military authorities of enemy countries, regardless of rank, who ordered or failed to prevent violations of the laws or customs of war; ${ }^{150}$ and (4) such other persons who were most appropriately tried before an international tribunal. ${ }^{151}$ Of note, the high tribunal would also have preference over national courts for the same offence, have the ability to transfer cases to national courts for inquiry or for trial and judgment, and would allow for prosecutorial discretion in case selection. ${ }^{152}$

The Commission stated that the tribunal would apply "the principles of the law of nations as they result from the usages established among civilized peoples, from the laws of humanity and from the dictates of public conscience." 153 This language drawn from the Martens Clause would set sufficient parameters to allow for the trial of war criminals. The tribunal would "have the power to sentence [the guilty party] to such punishment or

25 Rev. Gen. De Droit InT. Pub. 25). See also Carlos S. Nino, The Duty to Punish Past Abuses of Human Rights Put Into Context: The Case of Argentina, 100 YALE L. J. 2619, 2638-39 (1991):

Violations of human rights belong with crimes such as terrorism, narcoticstrafficking, and destabilizing democratic governments, in a category of deeds which may, because of their magnitude, exceed the capacity of national courts to handle internally. ... But if the establishment of international courts seems impossible, intermediate solutions could be implemented, such as the internationalization of jurisdiction, and the refusal of foreign courts to recognize amnesties, pardons, or special statutes of limitations for these kinds of crimes.

149. Commission Report, supra note 135, at 121 (stating that each belligerent had the right to form "an appropriate tribunal, military or civil, for the trial of such cases ... [which] would be able to try the incriminated persons according to their own procedure, and much complication and consequent delay would be avoided which would arise if all such cases were to be brought before a single tribunal"). Again, this follows the recommendation and model law of the 1880 Manual of the Laws of War on Land, supra note 81.

150. Commission Report, supra note 135, at 121 (authorizing trial of "all authorities, civil or military, belonging to enemy countries, however high their position may have been, without distinction of rank, including the heads of states, who ordered, or, with knowledge thereof and with power to intervene, abstained from preventing or taking measures to prevent, putting an end to or repressing, violations of the laws or customs of war).

151. Id. at 121-22.

152. Id. at 122. For example, the Commission plan states "the duty of selecting the cases for trial before the tribunal and of directing and conducting prosecutions before it shall be imposed upon a Prosecuting Commission of five members ...."

153. Id. 
punishments as may be imposed for such an offence or offences by any court in any country represented on the tribunal or in the country of the convicted person." 154 Looking at the list of crimes reported by the Commission, the crimes are neither divided between war crimes and crimes against humanity, nor are they systematically compiled. ${ }^{155}$ Instead, the list is illustrative of "diverse" and "painful" crimes, with additions "daily and continually being made." Commission sought to challenge this fairly expansive power. The Martens Clause had matured into settled law for the states that had participated in the conferences leading to the Hague Conventions of 1899 and $1907 .{ }^{157}$

\section{E. Challenges to the 1919 Commission Report}

In its challenges to the Commission Report, the US delegates raised a number of issues deriving from a claimed distinction between legal and moral obligations: the United States noted that "[t]he laws and customs of war are a standard certain, to be found in books of authority and in the practice of nations," while the "laws and principles of humanity vary with the individual," preventing them from being considered in a court of justice, particularly in the administration of criminal law. ${ }^{158}$ Rather than vindicating

154. Id.

155. Sandoz, supra note 108, at 668-69 (arguing that the list, while "somewhat interesting historically, ... cannot be viewed as the result of a serious and systematic work of scholarship carried out to show established doctrine or state practice.").

156. Commission Report, supra note 135, at 113-115.

157. Although only ten of the fifteen signatories to the 1907 Hague.Convention served on the Commission on Responsibilities, eight of the ten - all but the United States and Japanrecognized the Commission's Majority Report without reservation.

158. Commission Report, supra note 135, at 134 (the United States representatives here distinguish between responsibilities of a legal nature and those of a moral nature). See also id. at 128. But see id. at 136 (arguing to the political question of sovereignty and head of state immunity); id at 139-140 (distinguishing to the submission of a non-binding commission of inquiry for aggressive war, to the extent anybody can investigate and distinguish between an aggressive and defensive posture, and to note that such a body would be responding to a moral and not legal question); $c f . i d$. at 146 (noting that tribunals to hear war crimes must consider only war crimes over which the individual states already have jurisdiction, as there was "no international statute or convention making a violation of the laws and customs of war-not to speak of the laws or principles of humanity-an international crime, affixing a punishment to it, and declaring the court which has jurisdiction over the offence"); $c f$. $i d$. at 147 (noting the United States was "averse to the creation of a new tribunal, of a new law, of a new penalty, which would be ex post facto in nature, and thus contrary to the Constitution of the United States and in conflict with the law and practice of civilized communities"); $c f$. id. at 148 (noting that heads of state who violate the laws and customs of war "are, as agents of the people, in whom the sovereignty of the state resides, responsible to the people for the illegal acts which they may have committed, and that they are not and that they should not be made responsible to any other sovereignty"); $c f$. id. at 129,149 (stating that a head of state is morally, but not legally, 
rights that exist according to the laws or principles of humanity-- a term negotiated, adopted, and utilized within a European context-- the United States looked to apply the written laws of the parties regarding their own courts applying penal laws to enemy belligerents. ${ }^{159}$

The Japanese delegates similarly questioned whether international law recognized a penal law for a belligerent presumed guilty of a crime against the laws and customs of war, but appeared to challenge only the inclusion of heads of state in those to be charged under high tribunal, and the punishment for failure to "abstain[] from preventing or taking measures to prevent, put[] an end to, or repress[] acts in violation of the laws and customs of war." 160 Thus, while the European members of the Commission on Responsibility looked to interpretations of law developed through and internalized following the Brussels Declaration and Hague Conventions, the United States and Japan did not recognize the developments as having achieved the standard of law in a strict sense.

Eventually, following the first World War, the Allied governments decided to limit their requests, "only want[ing] to make an example. To try very large numbers would be to create great difficulties for the German Government," which some states viewed as easier to work with than a potential Bolshevist or Militarist Government. ${ }^{161}$ State leaders shifted the membership of the Inter-Allied Mixed Commission ${ }^{162}$ from legal experts to those who would assist in the political expedient of selecting a number of cases for Germany to conduct, "to uphold moral principles and treaty rights." 163

While maintaining the commission structure, this signified the move toward a political solution over a legal one, moving away from legal concepts such as deterrence of, retribution against, and reparations from individual perpetrators toward recognition of culpability and reparations by the state. Thus, while states recognized the harm done by the parties

responsible to mankind, such that the authority of the Commission was circumscribed by its mandate: to report on "facts as to the violations of the laws and customs of war committed by the forces of the German Empire and its allies ...").

159. Commission Report, supra note 135, at 135.

160. M. Adatci \& S. Tachi, Reservations by the Japanese Delegation (Apr. 4, 1919), 14 AM. J. INT'L L. 70, 152 (1920).

161. Willis, supra note 144, at 117 (referencing the English view that the Allies should seek the surrender of "the most important and notorious offenders and let the rest go," and the French view to commence with "a few symbolic persons."). While even a shortened list of Germans sought by the Allies for trial had 1,580 alleged offenders on it, compromise among the Allies brought the list down to 890. Eventually, the Allies allowed Germany to try an almost negligible number of alleged war criminals.

162. The Inter-Allied Mixed Commission was formed to "collect, publish and communicate to Germany details of the accusations made against each of the responsible persons" for war crimes during World War I. See Allied Note to President of German Delegation Respecting War Criminals, May 7, 1920, in 16 (4) Supp. AM. J. INT'L L. 195, 196 (1922).

163. Willis, supra note 144 , at 124. 
defeated during the war and could specify the criminal nature of that harm such that a majority of those states could agree to the propriety of criminal sanctions, political and economic expediency allowed the states to, in large part, step away from criminal process in response to war crimes and crimes against humanity.

\section{F. The Nuremberg Charter of the International Military Tribunal}

Thus far, we have seen that Europe and increasingly, other world powers develop penalties for crimes engaged in during a conflict use war and legal issues raised through the conflict to crystallize legal questions regarding rights and responsibilities of parties to the conflict. Following the first World War, most of the great Powers of Europe had recognized a legal standard, but were unwilling or unable to enforce that standard.

The twentieth-century saw the rise of a voluntary-positivist view of international law - law as an expression of the will of the state, based in a specific, legally cognizable source on which the state representative might rely. ${ }^{164}$ In applying international law, the international community had to decide what weight to give arguments stating that a law reached customary status, or reflected a general principle. ${ }^{165}$ This happens whether the international community can interpret international law through a designated international body, or allows for interpretation of the law to

164. While we certainly saw as much in the United States response to crimes against humanity in the Commission report following World War I, we also see the International Court of Justice struggle with sources of law. See, e.g., Competence of the General Assembly for the Admission of a State to the United Nations, Advisory Opinion, 1950 I.C.J. 5 (Mar. 3, 1950) (dissenting opinion of ICJ Judge Alvarez):

The common view that international law must be created solely by States is, therefore, not valid to-day-nor indeed has it ever been.... [New International Law's] point of departure is that, to-day, States are increasingly interdependent: and that consequently they do not form a simple community, as formerly, but rather a veritable international and organized society. This society in nowise abolishes the independence and the sovereignty of the States, nor their legal equality (Article 2 paragraph 1, of the Charter); but it limits this sovereignty, and the rights which flow therefrom, in view of the general interests of this society.

In accordance with the Preamble to the Charter, the new organization- and consequently, the new law which flows therefrom- must have the following ends in view: to maintain peace, to consider the general interest, to safeguard fundamental human rights, to promote co-operation between States, to bring their interests into harmony, to promote economic, social, intellectual and humanitarian progress. The old individualistic law had none of these purposes; it took account only of the interests of the individual [state] considered in isolation.

Id. at 13-14.

165. Id. 
devolve back to the states.

The bases of international law were recognized and formalized by the international community in the Charter of the Permanent Court of International Justice, to be later restated in the Statute of the International Court of Justice. ${ }^{166}$ Independent sources of international law include treaty law, customary international law, and general principles of law, with decisions of jurists and writings of scholars take on a supportive role in understanding the law. ${ }^{167}$ These sources are a minimum - that is, courts may look to these sources and give them weight, notwithstanding arguments made by a party before the court that a particular source is not properly law. ${ }^{168}$ The dynamics underpinning all of these sources of law were hotly debated at the end of World War II, ${ }^{169}$ when the question of what international criminal justice mechanisms were desirable, available, and enforceable loomed large.

The victorious states, as the United Nations, ${ }^{170}$ prepared for the prosecution of Nazi war criminals at the end of World War II. The US delegate to the United Nations War Crimes Commission, Herbert Pell, sought retribution for atrocities committed against people on racial or religious grounds based on the application of the "laws of humanity" and suggested crimes committed against persons based on their race or religion constituted "crimes against humanity.","171

British prosecutor Hartley Shawcross noted that crimes against humanity were different in kind from the crime against peace and the ordinary war crime. To a certain extent, the crime was carried out as part of the Nazi Party's total war policy, thereby raising international issues of

166. U.N. Charter, Statute of the International Court of Justice, 59 Stat. 1055, T.S. 993 (1945) [hereinafter U.N. Charter].

167. Id. art. $38(1)$.

168. See, e.g., Maritime Delimitation and Territorial Questions (Qatar v. Bahrain), 1994 I.C.J. 112 (July 1994) (where the International Court of Justice finds the existence of a treaty notwithstanding denial of intent to treat meeting minutes as binding by party seeking to challenge I.C.J. jurisdiction.).

169. Formulation of the Nürnberg Principles, 2 Yв. Int'l. L. Comm'n. 181,182-88 (1950). Indeed, at a meeting of the International Law Commission in 1949, member Georges Scelle proposed that the International Law Commission "also formulate the general principles of international law underlying the Charter and the judgment [of the Nürnberg Court]," but the proposal was rejected. Id. at 189.

170. The term "United Nations" in its current context was first used in a document describing twenty-six nations united "in the struggle for victory over Hitlerism." See United Nations, Declaration by United Nations (Jan. 1, 1942), http://untreaty.un.org/cod/avl/ ha/cun/photo06.html; see also United Nations, History of the United Nations, http://www.un.org/en/aboutun/history/ (last visited May 17, 2013) (describing the United Nations' history).

171. Michael R. Marrus, The Nuremberg War Crimes Trial 1945-46: A Documentary History 186 (Bedford Books 1997). 
crimes against peace. ${ }^{172}$ However, in addition to its impact on the international community, its criminalization derived from "matters which the criminal law of all countries would normally stigmatize as crimesmurder, extermination, enslavement, persecution on political, racial or economic grounds." 173 "Shawcross noted that the nations adhering to the Nuremberg Charter "felt it proper and necessary and in the interest of civilization to say that these things ... . were, when committed with the intention of affecting the international community ... not mere matters of domestic concern but crimes against the law of nations . . .,"174

Again, we see the effects of a transnational legal process, albeit one in which the victorious powers following a conflict also acted with power in the domestic sphere as occupying forces. Notwithstanding that, there was the interaction of states and peoples - both allies and enemies - during a time of war and soon thereafter, trying to clarify the scope and nature of international criminal justice. As a supranational or international community, the rules that should have protected populations needed to be interpreted in a way that was acceptable within a legal framework, both by the prosecuting states and the citizens of states subject to trial; in doing so, the states and international community internalized the notion that these crimes were cognizable in the international sphere. By setting parameters for punishment following a specific conflict, the United Nations recognized an applicable international criminal system, and set about attempting to codify it, internalizing it for the victorious states as well as for those defeated during the war.

\section{G. Development of Atrocity Crime Regulation Since Nuremberg}

In the years since Nuremberg, the scope of the jurisdiction of international tribunals has expanded in some contexts and faltered in others. This splintered approach reflects political pressures, financial constraints, decisions made based on prosecutorial discretion, and a persistent ambivalence toward international jurisdiction over atrocity crimes. Notwithstanding the inconsistencies in the approach of the United Nations bodies and member states responding to international criminal law issues, the trend of non-governmental organizations, the UN system, and states has been toward the development of standards and processes to enable the prosecution of international crimes.

One of the initial agenda items of the nascent United Nations organization was the codification of the Nuremberg Principles, undertaken

172. Id. at 188 .

173. Id. at $188-89$ (citing Trial of the Major War Criminals before the International Military Tribunal, Nuremberg, 14 November 1945-1 October 1946, 42 vols. 19:470-72 (Nuremberg International Military Tribunal, 1947)).

174. Id. 
by the International Law Commission in a Draft Code of Offences against the Peace and Security of Mankind. ${ }^{175}$ The International Committee for the Red Cross prepared a draft of re-articulated international humanitarian law, which after diplomatic Conferences in Geneva became the 1949 Geneva Conventions; some aspects of the Geneva Conventions clarified the need for states to prosecute grave breaches of the Laws of Armed Conflict. ${ }^{176}$

The early 1950s saw an advance toward the ICC, and a move toward the end of impunity for war crimes and crimes against humanity (including genocide) was progressing well. The international community came to accept that "[i]nternational law now protects individual citizens against abuses of power by their governments [and] imposes individual liability on government officials who commit grave war crimes, genocide, and crimes against humanity." 177 The General Assembly unanimously affirmed the principles of the Nuremberg Charter, which many courts, international and municipal, have understood as an authoritative declaration of customary international law. ${ }^{178}$

During the Cold War, distrust and power imbalances prevented the on-going codification and development of international criminal law, with some exceptions, prior to the development of the ad hoc tribunals. ${ }^{179}$ Despite this period where the growth of international criminal law slowed, development of international criminal law has increased greatly with ad hoc tribunals, the creation of the ICC, and the development of international

175. Formulation of the Principles Recognized in the Charter of the Nürnberg Tribunal and in the Judgment of the Tribunal, G.A./Res./177(II) (Nov. 21, 1947), available at http://daccess-dds-ny.un.org/doc/RESOLUTION/GEN/NR0/038/84/IMG/NR003884.pdf?

OpenElement:

[T] entrust the formulation of the principles of international law recognized in the Charter of the Nürnberg Tribunal and in the judgment of the Tribunal to the International Law Commission, the members of which will, in accordance with resolution 174 (II), be elected at the next session of the General Assembly, and directs the Commission to (a) Formulate the principles of international law recognized in the Charter of the Nürnberg Tribunal and in the judgment of the Tribunal, and (b) Prepare a draft code of offences against the peace and security of mankind, indicating clearly the place to be accorded on the principles mentioned in sub-paragraph (a) above.

Id.

176. Sandoz, supra note 108 , at $673-75$.

177. Anne-Marie Slaughter \& William Burke-White, An International Constitutional Moment, 43 HARV. INT'L L. J. 2, 13 (2002).

178. Michael P. Scharf, Seizing the "Grotian Moment": Accelerated Formation of Customary International Law in Times of Fundamental Change, 43 CORNELL INT'L L. J. 449, 455 (2010).

179. See generally BRUCE Broomhall, INTERNATIONAL CRIMINal JuSTICE AND THE INTERNATIONAL CRIMINAL COURT (Oxford 2003) (arguing that the Cold War period represented a time during which nations emphasized geopolitical concerns over the prosecution of war crimes); Frédéric Mégret, The Politics of International Criminal Justice, 13(5) EUR. J. INT'L L.1261 (2002). 
criminal law claims in national jurisdictions.

The first half of the twentieth century had raised the possibility of greater accountability for atrocities. Despite a lack of prosecutions, the arguments raised in the recommendation of the 1919 Commission on the Responsibility of the Authors of the War and on Enforcement of Penalties ${ }^{180}$ advanced legal standards. Twenty-two perpetrators prosecuted at the IMT Nuremberg trial, as opposed to the trials of over 1,000 alleged perpetrators of war crimes and crimes against humanity pursued under Control Council Law No. 10 by military tribunals in occupied Germany and in liberated or Allied nations, ${ }^{181}$ already reflected a growth in the possibility of prosecutions of international crimes at international and domestic levels, even where the domestic courts were under the authority of occupying powers. The ICC and the ad hoc tribunals for the former Yugoslavia and for Rwanda allowed for a greater number of trials to occur, both in the courts themselves and outside the international court context both in the completion strategies' recognition of domestic courts and the expansion of complementarity. ${ }^{182}$

The question of the ICC's jurisdictional scope persists, with continued confusion regarding complementarity and the question of whether the ICC or national courts ought to try war crimes, atrocity crimes, and crimes against humanity. The reliance on the national courts makes structural sense, to the extent that the ICC recognizes the primacy of the national courts $^{183}$ and is a reserve court, intended to take cases only when the national courts are unwilling or unable to prosecute the case,

180. Again, but for the four areas of exceptional cases recommended for an international or mixed tribunal, the Commission recognized the right of each belligerent to try "incriminated persons" in the belligerent's custody in an appropriate military or civil tribunal existing under, or set up pursuant to, national legislation, and according to the belligerent's own procedure. Commission Report, supra note 135, at 121 . Presumably the vast number of trials would have taken place within a national jurisdiction.

181. Scharf, supra note 178, at 454; KLEFFNER, supra note 2, at 34 (for the claim of over 17,000 prosecutions in East Germany for crimes during the Second World War, with 1,800 for capital offenses, citing C.F. Rüter, Door Nederland Gezochte Oorlogsmisdadigers Allang Berecht Door de DDR - Prof. Rüter Krijgt Toegang Tot Stasi-achieven, 49 FolIA 1-2, 8-11 (1996)).

182. Indeed, the completion strategies for the ICTY, List of ICTY Completion Strategy Reports, http://www.icty.org/sid/10016 (last visited May 17, 2013), and the ICTR, International Criminal Tribunal for Rwanda, ICTR Complete Strategies, http://www.unictr. org/AboutICTR/ICTRCompletionStrategy/tabid/1 18/Default.aspx (last visited May 17, 2013), called for their prosecutors to transfer cases of mid-level and lower-level perpetrators to national courts to allow the international courts to focus on the most responsible senior leaders. This dual track calls for the expanded use of national courts to deal with admittedly international issues.

183. See Rome Statute, supra note 1, arts. 1, 17, 53, 58 (referencing complementarity, admissibility, and the issuance of a warrant of arrest when a case is within the jurisdiction of the Court). 
notwithstanding the national court's obligation to prosecute. ${ }^{184}$ Nevertheless, the Nuremberg Tribunal noted that individuals who commit a crime under international law can be punished for violations of international law. ${ }^{185}$ The differential posture of the Nuremberg Tribunal and the Rome Statute serve to highlight the tension in this area of concurrent powers between the international and national levels. Yet this tension is not new.

The International Law Commission clarified as early as 1950 that the duties imposed on individuals by international law require no interposition of internal law, and reiterated the principle in the 1954 Draft Code of Offences against the Peace and Security of Mankind. ${ }^{186}$ The responsibility for compliance lies with the people, and the remedy for a breach should be immediately available, without further action taken by their leaders or government agents prior to the enforceability of the peoples' rights. Thus, the United Nations and its members recognized a right existing in individual persons, and prosecutable against individual perpetrators.

However, it may be difficult to vindicate a right that individuals cannot pin down. In revisiting the language of the crimes against humanity provision of the Nuremberg Charter, interaction and interpretation led to fragmentation of an understanding of the crime's definition. For example, the 1954 Draft Code of Offences against the Peace and Security of Mankind specifically referenced (a non-exhaustive list of) crimes against humanity in the context of whether such crimes must be in the context of a war. ${ }^{187}$ The 1991 Draft Code of Crimes Against the Peace and Security of Mankind referenced the same material, but expanded it into "Systematic or Mass Violations of Human Rights," and to conform to the principle of nullum crimen sine lege, purported to make the list exhaustive. ${ }^{188}$

Because the violation of human rights would need to be of an extremely serious character, only systematic violation such as a constant practice or a methodical plan or mass scale (based on the number of people or the size of the entity affected) violations would fall within the 1991 Code. ${ }^{189}$ The party violating the human right could be a public official, or "private individuals with de facto power or organized in criminal gangs or groups might also commit the kind of systemic or mass violations of human rights covered by the article . ..."

184. See id. pmbl. ๆ $4,6, \&$ art. 1; Kleffner, The Impact of Complementarity, supra note 32 , at 93-94.

185. Nazi Conspiracy and Aggression: Opinion and Judgment, 1 Int'l Mil. Trib. 52 (1947); Draft Code of Crimes Against the Peace and Security of Mankind, 2 Y.B. Int'l L. Comm'n 18 (1996) [hereinafter Draft Code] (emphasis added).

186. 2 Y.B. Int'l L. Comm'n 150 (1954).

187. Id.

188. See 2 Y.B. Int'l L.Comm'n 103-04 (1991).

189. Id. at 103 .

190. Id. At 103-04. 
human rights abuse was framed quite differently from the crime against humanity claims brought before the Nuremberg Tribunal. ${ }^{191}$

The 1993 and 1994 International Criminal Tribunals for the Former Yugoslavia (hereinafter, the "ICTY") and for Rwanda (hereinafter, the "ICTR"), respectively, split the difference in terms of their treatment of crimes against humanity for jurisdictional purposes. The ICTY Statute required that the perpetrator commit the crime against humanity during an armed conflict, but expanded the definition of the crime to include "other inhumane acts," such that the list no longer purports to be exhaustive. ${ }^{192}$ The ICTR Statute, on the other hand, did not require that crimes against humanity occur during armed conflict, but that the perpetrator must "commit [the crime] as part of a widespread or systematic attack against any civilian population on national, political, ethnic, racial or religious grounds ....."193

The International Law Commission continued to develop and codify the laws allowing for the prosecution of these international crimes, with additional changes. The 1996 Draft Code of Crimes Against the Peace and Security of Mankind requires that a crime against humanity be "committed in a systematic manner or on a large scale and [be] instigated or directed by a Government or by any organization or group."194 The International Law Commission commentary to the Draft Code claims to apply "the Charter of the Nürnberg Tribunal, as interpreted and applied by the Nürnberg Tribunal, taking into account subsequent developments in international law since Nürnberg." 195

Instead of relying on the standard requiring a massive human rights violation to qualify as a crime against humanity, as indicated in the 1991 Code, the 1996 Code points out that the Nazi policy of terror was "certainly carried out on a vast scale," in order to suggest that, if the crime is not systemic, but is widespread, it can still qualify as a crime against humanity. ${ }^{196}$ This mirrors the type of standard and language used since the

191. But see Schabas, supra note 4, at 536 (noting that, with the end of the Cold War and fall of the Berlin Wall, proposals for an international criminal court were strengthened by the growing emphasis of the human rights movement on accountability for atrocity crimes).

192. International Tribunal for the Prosecution of Persons Responsible for Serious Violations of International Humanitarian Law Committed in the Territory of the Former Yugoslavia since 1991, Updated Statute

of the International Criminal Tribunal For The Former Yugoslavia http://www.icty.org/ x/file/Legal\%20Library/Statute/statute_sept09_en.pdf (last visited May 17, 2013).

193. United Nations, International Criminal Tribunal for Rwanda (ICTR): Statute of the International Criminal Tribunal for Rwanda, 61, http://www.unictr.org/Portals/0/English/ Legal/Statute/2010.pdf (last visited May 17, 2013).

194. Draft Code, supra note 185, at 47.

195. Id.

196. Id. 
time of the Lieber Code. ${ }^{197}$ The requirement of group instigation or direction of the 1996 Code was new, and was intended "to exclude the situation in which an individual commits an inhumane act while acting on his own initiative pursuant to his own plan ... [particularly as] it would be extremely difficult for a single individual acting alone to commit the inhumane acts as envisaged in article 18 [the Crimes Against Humanity provision]." ${ }^{\prime 198}$ These variances in treatment by the Draft Codes of 1991 and 1996 serve to illustrate the ongoing tension in defining what acts are grave enough to qualify as crimes against humanity and, therefore, should qualify for admissibility before the ICC.

The Rome Statute defines Crimes Against Humanity as "any of the following acts [listing acts virtually identical to the 1996 Draft Code] when committed as part of a widespread or systematic attack directed against any civilian population, with knowledge of the attack." 199 Not surprisingly, when U.S. Senators Durbin, Leahy, and Feingold introduced the Crimes Against Humanity Act of 2009, the Act tracked the language of the Rome Statute. ${ }^{200}$

The baseline for a crime against humanity, specifically its attack requirement, appears to be higher than the standard set in the 1996 Draft Code, and different than the standard for crimes against humanity in the ICTY and ICTR Statutes. Thus, the standard appears to be narrower from the International Law Commission recommendation, notwithstanding the recognition by a majority of UN member states that the ICC has jurisdiction, that the United Nations through the Security Council may refer matters to the ICC under Security Council authority to maintain international peace and security, ${ }^{201}$ and that the right to protection from these harms belongs to individuals under international law, not to citizens

197. Id.

198. Id.

199. Rome Statute, supra note 1 , art.7.

200. See Scheffer, supra note 14, at 25-28. Ambassador Scheffer noted that the Act required the attack be systematic and widespread, while the Rome Statute allows for the attack on a civilian population to be systematic or widespread - but, given that the Rome Statute definition describes an "attack directed against any civilian population" to mean "a course of conduct involving the multiple commission of acts referred to in [the listing of crimes against humanity] against any civilian population, pursuant to or in furtherance of a State or organizational policy to commit such attack . . ., the crime must be widespread (multiple commission) and systematic (pursuant to a policy), as formulated by the Rome Statute Elements of Crimes. $I d$. at 27. Thus, while the wording of the crime appears to be stricter than wording found anywhere else protecting against crimes against humanity, the distinction made no difference.

201. See U.N. Charter, supra note 166 , arts. $39,41,42$. The authority of the Security Council has been the basis for referrals to the ICC in the situations in Darfur, Sudan, and in Libya, both non-parties to the Rome Statute at the time of referral (for a description of situations before the ICC, see http://www.icc-cpi.int/en_menus/icc/situations $\% 20$ and $\%$ 20 cases/Pages/situations $\% 20$ and $\% 20$ cases.aspx). 
of states through their state governments.

Assuming that the state has an obligation in the international sphere to enforce the international understanding of crimes against humanity and a responsibility to protect individuals within its borders from international crimes, it is unclear in this fragmented model which definition would apply. It could be the Draft Code as custom derived from state practice by the International Law Commission, or the Rome Statute as Treaty and the customary law adopted by over 120 states, or even the international tribunals created by the Security Council that have been in existence for nearly twenty years.

\section{MOVING FORWARD: THE ROLE AND OBLIGATION OF NATIONAL COURTS}

Previous parts of this Article outlined some of the failures of the ICC to live up to its potential and have traced the historical patterns that suggest that the ICC will continue to narrow its jurisdictional scope. This part offers potential solutions by considering how the current quandary surrounding ICC complementarity and definitions of gravity can motivate national courts to prosecute war crimes and engage in essential norm-setting behavior that will resonate on both the national and international level.

The fact that ICC jurisdictional standards are still malleable creates the opportunity for national leaders and agents, judges, and nongovernmental organizations to demand a decrease in barriers when seeking a remedy, a greater number of trials, and the implementation of laws of the ICC as the law of the state by seeking the adoption of terms broader than that of the ICC statute as legislation within the state. While the perceived lack of legitimacy of national courts may indeed be an issue, the national courts' implementation of a lower threshold to entry than that of the ICC may be the only manner to effect both the underlying purpose of the Court, and to create a body of law from which other international criminal cases can begin the process of interaction anew.

In addition, the international community has evolved in not only recognizing a duty under international law to prosecute international crimes as defined by international law, but also a responsibility to protect our populations from the very harms caused by atrocity crimes. ${ }^{202}$ In addition to the obligation to give effect to criminal law recognized in the Rome Statute, the United Nations has recognized that primary protection falls to the state with secondary responsibility exercisable by the international community through the UN Security Council. ${ }^{203}$ This secondary right in the

202. See Charity, supra note 28 , at $90-109$ (detailing the development and standards under the Responsibility to Protect).

203. 2005 World Summit Outcome, supra note 97, fif 138-39. 
international community to invest in state security even against national will is also exercisable through the Security Council, which can refer matters to the ICC, and delay the matter's consideration in the interest of international peace and security. ${ }^{204}$

In the meantime, the progressive narrowing of the ICC jurisdiction has the potential to wreak immediate and problematic effects. For example, while the conflicts in the Great Lakes region of Africa may continue for years to come $^{205}$ actions surrounding the ICC have also given some evidence of compliance pull in the application of amnesty laws in Uganda ${ }^{206}$ In communications with the ICC, Uganda was able to pass an amnesty law for the largest portion of those involved in regional conflict, while retaining the ICC as a reserve court. ${ }^{207}$ If that decision does not work to Uganda's benefit, the compliance pull for such an act will decrease, and the Court will not establish a norm in support of similar negotiations. ${ }^{208}$ In

204. Rome Statute, supra note 1 , arts. 14 \& 16.

205. See, e.g., Jon Lunn, The African Great Lakes Region: An End to Conflict?, HouSE OF COMMONS (Research Paper 06/51), at 4 (2006), available at http://www.stabilisationunit. gov.uk/stabilisation-and-conflict-resources/geographic/doc_details/328-the-african-great-lakesregion-an-end-to-conflict.html:

The conflicts of the last decade across the African Great Lakes region must be understood in the context of longer-term dynamics of ethnic conflict and state formation. In doing so, it is particularly important to study patterns of intervention in each other's affairs by the states of the region and the role of natural resources in fuelling conflict. Three factors have been identified by analysts as key contributors to conflict in the region: ethnicity, state failure and greed. Peace-building strategies have increasingly sought to address both political and economic issues and to incorporate regional and international dimensions.

Even as political solutions move forward, it remains imperative to support the legal legitimacy of those solutions, as noted recently by Raphael Wakenge, Coordinator of the Congolese Initiative for Justice and Peace (ICJP):

We need a new approach, a peace process based on the principles of justice. Past peace deals have often closed their eyes toward impunity, allowing war criminals to be integrated into the army, police and security services. This has undermined the legitimacy of the peace process and the reputation of the security services, including the judiciary.

quoted in Richard Lee, Southern Africa: DRC Peace Deal Is Just the Start, OPEN SOCIETY INITIATIVE FOR SOUTHERN AFRICA (Feb. 26, 2013), http://allafrica.com/stories/ 201302260686.html.

206. That is, there appears to be some quality in the law that may induce, but not necessarily compel, adherence (compliance) without necessarily reflecting obedience or recognition of a legal requirement in and of itself. For a more in depth discussion of theories of legitimacy and compliance pull, see Kal Raustiala and Anne-Marie Slaughter, International Law, International Relations and Compliance, in HANDBOOK OF INTERNATIONAL RELATIONS 538 (2002).

207. See Uganda: Amnesty Act Without Amnesty, AllAfriCA (June 3, 2012), http://allafrica.com/stories/201206040501.html.

208. See KLEFFNER, supra note 2, at 325 (noting that in addition to support for norm creation through a transnational/supranational dialogue, the negotiations recognize different 
short, the crimes against humanity that may be occurring in the course of this conflict will go unpunished, and the lack of criminal liability will only embolden future perpetrators of atrocity crimes.

\section{A. Decoupling International and National Mechanisms for the Prevention of Harms}

As there is a duality of international and national interest in the protection against atrocity crimes, there cannot be a clear demarcation between responsibilities for the prevention of these international harms, as the protection is one recognized by international law for the benefit of the individual. However, the proposed complementarity requires a demarcation between the opportunity for state jurisdiction and international jurisdiction in the punishment of these crimes. Although both the international and national communities have interests in the outcome and the protection of persons subject to these crimes, the outcome should not be determinative on the mechanisms used.

\section{B. International Purposes vs. National Purposes}

Looking at the question of the extent to which national courts served an international purpose, on the eve of the British election in October 1918, Lord Finlay, the Lord Chancellor, said to an Inter-Allied Parliamentary Committee: "Britain had "two aims in this war. One of them was the punishment of those who could be proved guilty of outrages,' and 'the other was reparation for the wrongs that had been done.' Prosecution of 'offenders would not be mere vengeance; it would be the vindication of international morality.",209

The question of control by the state apparatus of mechanisms to prevent the international crimes described in the Rome Treaty goes to the core of complementarity. As previously discussed, there exist numerous reasons that a local trial under the authority of a state with an interest in the outcome of the case would be preferable to an international trial. Only when the state exercising primary jurisdiction proves unable or unwilling to engage in genuine investigations or trials would the international tribunal

levels of criminality and gravity in the International Criminal Law sphere, and allow Uganda a voice in managing some of the lower level perpetrators). In addition to support for norm creation through a transnational/supranational dialogue, the negotiations recognize different levels of criminality and gravity in the International Criminal Law sphere, and allows Uganda a voice in managing some of the lower level perpetrators. See also Ewald, supra note 43, at 396; Baylis, supra note 31, at 44 (arguing that the adoption of the Rome Statute in certain cases in the Democratic Republic of Congo "is not an isolated importation of international law by the domestic system... [but is part of the] multiple, overlapping international-national interactions aimed at the more far-reaching goal of promoting postconflict justice by rebuilding the national justice system.").

209. See Willis, supra note 144, at 53. 
consider the admissibility of the case for international adjudication.

In attempting to prevent international harms, the state, as an entity in itself with responsibilities to its constituents, and as a member of the international community with responsibilities to the constituents of that community, may have different resources, limitations, and strengths than those available to an entity such as the ICC. The state-level apparatus will more likely have a clearly differentiated system of a judiciary, legislature, and executive.

All aspects of the state may have an interest in the outcome: some in responding to constituent concerns for vindication (perhaps as indicative of justice - i.e., the justice system will vindicate the rights of various classes of people), some in response to stability (either through prevention of escalation, or through maintenance of power structures that support the status quo within the state, or minimize individual needs or desires of various parties within the state), and some in application of their own authorities within the state (responsive executive desirous of recognition to a problem that a court cannot respond to with adequate alacrity). ${ }^{210}$ Some have argued that the international community attempts to replicate the governmental structures such that nothing immunizes the ICC from the concerns raised within a state structure. ${ }^{211}$

210. The writings of Georges Scelle on the permeability of the domaine réservé responds to this. A counterargument to state access to protection for those threatened by atrocities is now, and has always been, the concept of a domaine réservé - the space in which the state can distance itself from the encroachment of the international community. When the international community comes together and relinquishes authorities previously within the power of individual states to accomplish an international or transnational aim, the community creates a supranational system. In order for the system to function, there must be an agreement that the participants will follow the rule of law as expressed by the community. The government of a state must often represent the state in its international dealings, creating a dual role: both representing the interests of the constituents of the state, and representing a participant in the joint undertaking in a transnational sphere. Some international undertakings allow for or, indeed, require the actions of entities within a state system. One such example is the complementarity envisioned by the ICC Statute - while the international community responds to issues of concern, it does so because the actions are violative of both the international interest in the shared undertaking, as well as the constituents' individual interests. Scelle argues against states, such as the United States, that has an overbroad reading of the domaine réservé. See Scelle, supra note 88.

211. Scelle, supra note 88 , at 358 ("Social functions must be fulfilled in international collectives just as in national collectives, or the phenomenon of solidarity would rapidly disaggregate and the social tie would founder." [il faut que les fonctions sociales soient remplies dans les collectivités internationales comme dans les collectivités internes, sans quoi le phénomène de solidarité désagrégerait rapidement et le lien social péricliterait]). Scelle gives examples of the various branches of a state government acting with an international motive. 


\section{Why National Courts Must Act}

National courts were envisioned to be the primary actors in prosecuting international atrocity crimes and enforcing the growing global consensus that human rights norms must be protected and promoted. Although they are not currently fulfilling this role, their importance in establishing a strong framework of international criminal justice should not be understated.

As discussed, the state is well-positioned to take on this role: the preparation for the ICC planned around the concept of a reserve court; the complementarity provisions recognize a much more robust and active international community acting through national courts; and national courts are in at least as good a position to express the will of the States Parties to the ICC Statute as the ICC itself, until such time as the ICC has clarified its interpretation of the interpretive issues surrounding the crimes within its jurisdiction.

This is particularly true where there exists a gap between what the ICC purports to do, and what the Statute requires the member states to do in conjunction with the Court. The application of international criminal law has been, to a certain extent, a gap-filling exercise - allowing for us to recognize the imperfections in our protective processes, and to then better articulate standards and processes to close the gaps. However, there are times where the international community recognizes a gap that fails to protect a class originally considered for protection by legal process. ${ }^{212}$ Given the opportunity to protect that group, where parties do not reach an agreement on how to best do so, or whether it is in fact possible to do so, later arguments surrounding application and/or codification may lean towards implementing the gap as part of the law as accepted by states so as not to create new laws on which states have not agreed, or to expand on the laws recognized by states.

The application of the gravity standard by the ICC is paradigmatic; in raising what appears only an issue of complementarity, the ICC takes a risk by allowing state practice to redefine how crimes are prosecuted (or note prosecuted) within the ICC system. As noted in the case of Bosco Ntaganda, the ICC's controlling admissibility by refusing to hear cases involving serious crimes unless the alleged perpetrator is among those most responsible puts the onus on states parties to do the same - a cascading effect of impunity that is precisely the opposite of what the Rome Statute strived toward.

212. The development of the adoption of the Responsibility to Protect resolutions by the U.N. General Assembly and Security Council is an example of recognition of the international role in filling that gap-filling function. See generally, Charity, supra note 28 , at 94. 
If national courts apply International Criminal Law terms broadly, applying the terms as they understand the terms and wish them understood, it will serve to bolster the ICC as an institution and norm-setting body, since the ICC will then be in a better position to rely on the judgments made at various levels of responsibility, and to recognize an international harm, even when the ICC cannot or would not hear the case at an international level.

\section{CONCLUSION}

Within the realm of atrocity crimes, no answer will serve as a panacea for all humanity's ills. That does not mean that we should not continue working toward as many remedies as possible. The ICC, by design, requires input from various levels - from States Parties, to individuals seeking investigations by sending communications to the Office of the Prosecutor, to other entities seeking to resolve conflicts.

Where the individual members of the international community rely on the Appellate Chamber to set rules for the gravity of a harm subject to remedy, or allow for decisions to be relayed between the International Law Commission, the Office of the Prosecutor, and the leaders of States, individuals will have no voice in the international planning that would protect so many from systematic or widespread violence. Only by redoubling our efforts - through our legislatures, through our executive, through our courts, and through ourselves - will the international community be able to respond to our needs. 
